\title{
Kinetics of the Reactions of Allylsilanes, Allylgermanes, and Allylstannanes with Carbenium Ions
}

\author{
Gisela Hagen and Herbert Mayr*
}

Contribution from the Institut für Chemie der Medizinischen Universität zu Lübeck, Ratzeburger Allee 160, D-2400 Lübeck, Federal Republic of Germany. Received December 17, 1990

\begin{abstract}
Second-order rate constants for the reactions of para-substituted diarylcarbenium ions $\left(\mathrm{ArAr}^{\prime} \mathrm{CH}^{+}=1\right)$ with allylsilanes 2, allylgermanes 3, and allylstannanes 4 have been determined in $\mathrm{CH}_{2} \mathrm{Cl}_{2}$ solution at -70 to $-30^{\circ} \mathrm{C}$. Generally, the attack of $\mathrm{ArAr}^{\prime} \mathrm{CH}^{+}$at the $\mathrm{CC}$ double bond of the allylelement compounds 2-4 is rate-determining and leads to the formation of the $\beta$-element-stabilized carbenium ions 5 , which subsequently react with the negative counterions to give the substitution products 6 or the addition products 7. For compounds $\mathrm{H}_{2} \mathrm{C}=\mathrm{CHCH}_{2} \mathrm{MPh}_{3}$, the relative reactivities are $1(\mathrm{M}=\mathrm{Si}), 5.6(\mathrm{M}$ $=\mathrm{Ge})$, and $1600(\mathrm{M}=\mathrm{Sn})$. From the relative reactivities of compounds $\mathrm{H}_{2} \mathrm{C}=\mathrm{CHCH}_{2} \mathrm{X}\left(\mathrm{X}=\mathrm{H}, \mathrm{SiBu}_{3}, \mathrm{SnBu}_{3}\right)$, the activating effect of an allylic trialkylsilyl $\left(5 \times 10^{5}\right)$ and trialkylstannyl group $\left(3 \times 10^{9}\right)$ is derived. This effect is strongly reduced, when the alkyl groups at $\mathrm{Si}$ or $\mathrm{Sn}$ are replaced by inductively withdrawing substituents, and an allylic $\mathrm{SiCl}_{3}$ group deactivates by a factor of 300 (comparison isobutene/2k). A close analogy between the reactions of alkenes and allylelement compounds with carbenium ions is manifested, and the different reaction series are connected by well-behaved linear free energy relationships. The relative reactivities of terminal alkenes and allylelement compounds are almost independent of the electrophilicities of the reference carbenium ions (constant selectivity relationship), thus allowing the construction of a general nucleophilicity scale for these compounds.
\end{abstract}

Allylsilanes ${ }^{1}$ and allylstannanes ${ }^{2}$ have extensively been used as allyl anion equivalents during the last two decades. Their regioselective reactions with electrophiles have been explained by the intermediate formation of carbenium ions, which are hyperconjugatively stabilized by the carbon-silicon or carbon-tin bond in the $\beta$-position (Scheme I). ${ }^{3}$

Competition experiments have shown that allyltrimethylsilane is 5 orders of magnitude more reactive toward in situ generated diarylcarbenium ions than propene; i.e., the allylic trimethylsilyl group reduces the activation energy for electrophilic attack at the $\mathrm{CC}$ double bond by $18 \mathrm{~kJ} \mathrm{~mol}^{-1}$.

Analogous investigations on the effect of allylic germyl or stannyl groups on the nucleophilicity of $\mathrm{CC}$ double bonds have, to our best knowledge, not been performed. Indirect evidence for the magnitude of these effects can be obtained from the solvolysis rates of $\beta$-element-substituted alkyl halides ${ }^{5}$ or trifluoroacetates (Chart I), ${ }^{6}$ rates of acid-catalyzed $\mathrm{R}_{3} \mathrm{MOH}$ eliminations from $\beta$-metal-substituted alcohols, ${ }^{6}$ or the rates of hydride abstraction in alkyl-substituted silanes, germanes, and stannanes (Scheme II), ${ }^{7}$

(1) (a) Colvin, E. W. Silicon in Organic Synthesis; Butterworths: London, 1981. (b) Weber, W. P. Silicon Reagents for Organic Synthesis; Springer: Berlin, 1983. (c) Fleming, I. In Comprehensive Organic Chemistry; Barton, D. H. R., Ollis, W. D., Eds.; Pergamon Press: Oxford, 1979; Vol. III, p 541. (d) Sakurai, H. Pure Appl. Chem. 1982, 54, 1. (e) Schinzer, D. Synthesis 1988, 263. (f) Hosomi, A. Acc. Chem. Res. 1988, 21, 200. (g) Fleming, I.; Dunogues, J.; Smithers, R. Org. React. (N.Y.) 1989, 37, 57. (h) Eaborn, R.; Bott, W. In Organometallic Compounds of the Group IV Elements; MacDiarmid, A. G., Ed.; Marcel Dekker: New York, 1968; Vol. 1, Part 1.

(2) (a) Pereyre, M.; Quintard, J. P.; Rahm, A. Tin in Organic Synthesis; Butterworths: London, 1987. (b) Yamamoto, Y. Aldrichimica Acta 1987, 20, 45. (c) Yamamoto, Y., Ed. Organotin Compounds in Organic Synthesis. Tetrahedron Symposia-in-Print Number 36. Tetrahedron 1989, 45, 909.

(3) (a) Wierschke, S. G.; Chandrasekhar, J.; Jorgensen, W. L. J. Am. Chem. Soc. 1985, 107, 1496. (b) White, J. C.; Cave, R. J.; Davidson, E. R. J. Am. Chem. Soc. 1988, 110,6308 . (c) Ibrahim, M. R.; Jorgensen, W. L. J. Am. Chem. Soc. 1989, 111, 819. (d) Eaborn, C. J. Chem. Soc., Chem. Commun. 1972, 1255. (e) Lambert, J. B. Tetrahedron 1990, 46, 2677. (f) Apeloig, Y. In The Chemistry of Organic Silicon Compounds; Patai, S., Rappoport, Z., Eds.; John Wiley \& Sons: Chichester, 1989; Part 1, p 196.

(4) Mayr, H.: Pock, R. Tetrahedron 1986, 42, 4211.

(5) (a) Sommer, L. H.; Baughman, G. A. J. Am. Chem. Soc. 1961, 83 , 3346. (b) Cook, M. A.; Eaborn, C.; Walton, D. R. M. J. Organomet. Chem. $1970,24,301$.

(6) (a) Lambert, J. B.; Wang, G.; Teramura, D. H. J. Org. Chem. 1988,

53, 5422. (b) Lambert, J. B.; Wang, G. Tetrahedron Lett. 1988, 29, 2551.

(c) Lambert, B. J.; Wang, G.; Finzel, R. B.; Teramura, D. H. J. Am. Chem. Soc. 1987, 109, 7838.

(7) (a) Jerkunica, J. M.; Traylor, T. G. J. Am. Chem. Soc. 1971, 93, 6278.

(b) Traylor, T. G.; Koermer, G. S. J. Org. Chem. 1981, 46, 3651.
Scheme I

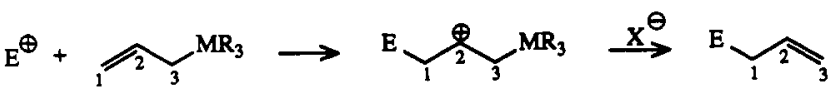

Scheme II. Rate Constants for Hydride Abstraction $\left(29.8^{\circ} \mathrm{C}\right.$, $\left.\mathrm{CH}_{3} \mathrm{CN}\right)^{7 \mathrm{a}}$

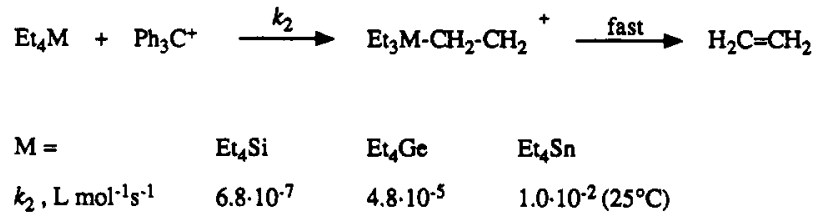

Chart I. Relative Solvolysis Rates of Cyclohexyl Trifluoroacetates in 97\% Trifluoroethanol at $25^{\circ} \mathrm{C}^{6 *}$<smiles>[X]C1CCCCC1OC(C)=O</smiles>

\begin{tabular}{ll}
\multicolumn{1}{c}{$\mathrm{X}$} & \multicolumn{1}{c}{$k_{\text {Tel }}$} \\
\multicolumn{1}{c}{$\mathrm{H}$} & 1.0 \\
cis-SiMe & $3.3 \cdot 10^{4}$ \\
trans-SiMe & $5.7 \cdot 10^{9}$ \\
cis-GeMe & $4.6 \cdot 10^{5}$ \\
trans-GeMe & $1.0 \cdot 10^{11}$ \\
cis-SnMe & $>1.3 \cdot 10^{11}$ \\
trans-SnMe & $>10^{14}$
\end{tabular}

since in all these reactions $\beta$-element-substituted carbenium ions are formed in the rate-determining step. ${ }^{8}$

Recently we have developed a kinetic method to directly measure the rate of attack of carbenium ions at the $\mathrm{CC}$ double bond of alkenes. ${ }^{9}$ We now report that this method can also be

(8) Further examples for $\beta$-element stabilizations: (a) Hajdasz, D; Squires, R. J. Chem. Soc., Chem. Commun. 1988, 1212. (b) Li, X.; Stone, J. A. J. Am. Chem. Soc. 1989, 111 , 5586. (c) Ciommer, B.; Schwarz, H. J. Organomet. Chem. 1983, 244, 319. (d) Drewello, T.; Burgers, P. C.; Zummack, W.; Apeloig, Y.; Schwarz, H. Organometallics 1990, 9, 1161. 
Table I. Products from Lewis Acid Promoted Reactions of Diarylmethyl Chlorides with the Allylelement Compounds 2-4a,b

\begin{tabular}{|c|c|c|c|c|c|c|c|c|c|c|}
\hline $\mathbf{R}^{1}$ & $\mathbf{R}^{2}$ & $\mathbf{R}^{3}$ & $\mathbf{R}^{4}$ & $\mathrm{Y}$ & $\mathbf{Z}$ & $\begin{array}{c}\mathrm{ArAr}{ }^{\prime} \mathrm{CHCl} \\
\mathrm{mmol}\end{array}$ & $2-4, \mathrm{mmol}$ & Lewis acid, mmol & time $e^{c}$ & products $^{d}$ \\
\hline$\overline{\mathrm{H}}$ & $\mathrm{H}$ & $\mathbf{H}$ & $\mathrm{H}$ & $\mathrm{OMe}$ & $\mathbf{H}$ & 2.0 & $2 a / 7.0$ & $\mathrm{BCl}_{3} / 1.6$ & $40 \mathrm{he}^{\mathrm{e}}$ & none \\
\hline $\mathrm{H}$ & $\mathrm{H}$ & $\mathrm{H}$ & $\mathrm{H}$ & $\mathrm{OMe}$ & $\mathrm{H}$ & 3.0 & $2 b / 7.0$ & $\mathrm{BCl}_{3} / 2.0$ & $15 \mathrm{~h}$ & $6 a$ \\
\hline $\mathbf{H}$ & $\mathrm{H}$ & $\mathrm{H}$ & $\mathrm{H}$ & $\mathrm{OMe}$ & $\mathbf{H}$ & 4.5 & $2 \mathrm{c} / 4.5$ & $\mathrm{BCl}_{3} / 1.0$ & $20 \mathrm{~h}$ & $6 a / 7 a=3 / 2$ \\
\hline $\mathbf{H}$ & $\mathrm{H}$ & $\mathbf{H}$ & $\mathbf{H}$ & $\mathrm{Me}$ & $\mathrm{Me}$ & 5.2 & $2 \mathrm{e} / 5.5$ & $\mathrm{BCl}_{3} / 4.0$ & $2 \min$ & $6 b^{\prime}$ \\
\hline $\mathbf{H}$ & $\mathrm{H}$ & $\mathrm{H}$ & $\mathrm{H}$ & $\mathrm{OPh}$ & $\mathrm{H}$ & 4.1 & $2 \mathrm{e} / 4.4$ & $\mathrm{BCl}_{3} / 2.4$ & $2 \min$ & $6 c$ \\
\hline $\mathrm{H}$ & $\mathrm{H}$ & $\mathrm{H}$ & $\ddot{H}$ & $\mathrm{OMe}$ & $\mathrm{H}$ & 2.8 & $2 \mathrm{e} / 3.2$ & $\mathrm{BCl}_{3} / 1.6$ & $30 \mathrm{~min}$ & $6 \mathrm{a}$ \\
\hline $\mathbf{H}$ & $\mathrm{H}$ & $\mathbf{H}$ & $\mathbf{H}$ & $\mathrm{OMe}$ & $\mathrm{Me}$ & 12 & $2 e / 18$ & $\mathrm{BCl}_{3} / 2.8$ & $20 \mathrm{~min}$ & $6 d$ \\
\hline $\mathbf{H}$ & $\mathrm{H}$ & $\mathbf{H}$ & $\mathrm{H}$ & $\mathrm{OMe}$ & $\mathrm{OMe}$ & 7.6 & $2 \mathrm{e} / 9.6$ & $\mathrm{BCl}_{3} / 2.0$ & $2.5 \mathrm{~h}$ & $6 \mathbf{e}$ \\
\hline $\mathbf{H}$ & $\mathrm{H}$ & $\mathrm{H}$ & $\mathbf{H}$ & $\mathrm{OMe}$ & $\mathrm{OMe}$ & 1.9 & $2 \mathrm{e} / 2.3$ & TMSOTf $/ 2.2$ & $30 \mathrm{~min}$ & $6 e$ \\
\hline $\mathrm{H}$ & $\mathrm{H}$ & $\mathrm{H}$ & $\mathbf{H}$ & $\mathrm{OMe}$ & $\mathrm{H}$ & 2.1 & $2 f / 2.1$ & $\mathrm{BCl}_{3} / 2.0$ & $4 \mathrm{~h}$ & $\mathbf{7 b}$ \\
\hline $\mathbf{H}$ & $\mathrm{H}$ & $\mathbf{H}$ & $\mathbf{H}$ & $\mathrm{OMe}$ & $\mathrm{H}$ & 0.58 & $2 \mathrm{~g} / 0.83$ & $\mathrm{BCl}_{3} / 1.6$ & $1 \mathrm{~h}$ & $6 \mathrm{a}$ \\
\hline $\mathrm{H}$ & $\mathbf{H}$ & $\mathrm{H}$ & $\mathrm{H}$ & $\mathrm{OMe}$ & $\mathrm{H}$ & 2.2 & $2 \mathrm{~h} / 2.9$ & $\mathrm{BCl}_{3} / 0.8$ & $4 \mathrm{~h}$ & $7 c$ \\
\hline $\mathrm{H}$ & $\mathrm{H}$ & $\mathbf{H}$ & $\mathrm{H}$ & $\mathrm{OMe}$ & $\mathrm{H}$ & 4.0 & $2 i / 4.0$ & $\mathrm{BCl}_{3} / 1.8$ & $2 \mathrm{~h}$ & $6 \mathrm{a}$ \\
\hline $\mathbf{H}$ & $\mathrm{H}$ & $\mathbf{H}$ & $\mathrm{H}$ & $\mathrm{OMe}$ & $\mathrm{H}$ & 2.2 & $2 \mathbf{j} / 2.2$ & $\mathrm{BCl}_{3} / 1.0$ & $3 \mathrm{~h}$ & $6 \mathbf{a}$ \\
\hline $\mathbf{H}$ & $\mathrm{H}$ & $\mathrm{Me}$ & $\mathrm{H}$ & $\mathrm{OMe}$ & $\mathrm{H}$ & 4.3 & $2 \mathbf{k} / 5.0$ & $\mathrm{BCl}_{3} / 2.0$ & $14 \mathrm{~h}$ & $6 f$ \\
\hline H & $\mathrm{H}$ & $\mathrm{Me}$ & $\mathbf{H}$ & $\mathrm{OMe}$ & $\mathrm{H}$ & 3.9 & $21 / 3.9$ & $\mathrm{BCl}_{3} / 1.2$ & $2 \min$ & $6 f$ \\
\hline $\mathrm{H}$ & $\mathrm{H}$ & $\mathrm{Me}$ & $\mathbf{H}$ & $\mathrm{OMe}$ & $\mathrm{H}$ & 1.5 & $2 \mathrm{~m} / 1.5$ & $\mathrm{BCl}_{3} / 0.8$ & $2 \min$ & $6 f$ \\
\hline $\mathrm{H}$ & $\mathrm{H}$ & $\mathrm{Me}$ & $\mathbf{H}$ & $\mathrm{OMe}$ & $\mathrm{OMe}$ & 1.0 & $2 \mathrm{~m} / 1.2$ & $\mathrm{BCl}_{3} / 1.2$ & $2 \mathrm{~h}$ & $6 \mathrm{~g}$ \\
\hline $\mathrm{H}$ & $\mathrm{Me}$ & $\mathbf{H}$ & $\mathrm{H}$ & $\mathrm{OMe}$ & $\mathrm{H}$ & 0.65 & $2 n / 0.4$ & $\mathrm{ZnCl}_{2} / 0.31^{f}$ & $14 \mathrm{~min}$ & $6 \mathrm{~h}$ \\
\hline Me & $\mathrm{Me}$ & $\mathrm{H}$ & $\mathbf{H}$ & $\mathrm{OPh}$ & $\mathrm{H}$ & 2.0 & $2 p / 2.2$ & $\mathrm{BCl}_{3} / 2.8$ & $1 \mathrm{~min}$ & $6 \mathbf{i}$ \\
\hline Me & $\mathrm{Me}$ & $\mathbf{H}$ & $\mathrm{H}$ & $\mathrm{OMe}$ & $\mathrm{H}$ & 2.4 & $2 \mathrm{p} / 3.5$ & $\mathrm{BCl}_{3} / 1.7$ & $0.5 \mathrm{~min}$ & $\mathbf{6 j}$ \\
\hline Me & $\mathrm{Me}$ & $\mathbf{H}$ & $\mathbf{H}$ & $\mathrm{OMe}$ & $\mathrm{Me}$ & 2.0 & $2 p / 2.2$ & $\mathrm{BCl}_{3} / 0.8$ & $25 \mathrm{~min}$ & $6 \mathbf{k}$ \\
\hline Me & $\mathrm{Me}$ & $\mathbf{H}$ & $\mathbf{H}$ & $\mathrm{OMe}$ & $\mathrm{OPh}$ & 2.0 & $2 p / 2.2$ & $\mathrm{BCl}_{3} / 0.8$ & $1 \mathrm{~h}$ & 61 \\
\hline$-\mathrm{CH}_{2}-$ & $\mathrm{H}$ & $\mathrm{H}$ & $-\mathrm{CH}_{2}-$ & $\mathrm{OMe}$ & $\mathrm{H}$ & 4.4 & $2 q / 6.6$ & $\mathrm{BCl}_{3} / 2.0$ & $10 \mathrm{~min}$ & $6 \mathrm{~m}$ \\
\hline $\mathrm{Me}$ & $\mathrm{Me}$ & Me & $\mathbf{H}$ & $\mathrm{OMe}$ & $\mathrm{H}$ & 0.86 & $2 s / 1.3$ & $\mathrm{ZnCl}_{2} / 0.41^{f}$ & $1 \mathrm{~min}$ & $6 n$ \\
\hline Me & $\mathrm{Me}$ & $\mathrm{Me}$ & $\mathbf{H}$ & OMe & $\mathrm{OMe}$ & 2.3 & $2 s / 2.3$ & $\mathrm{BCl}_{3} / 1.2$ & $15 \mathrm{~min}$ & 60 \\
\hline H & $\mathrm{H}$ & $\mathrm{H}$ & $\mathrm{H}$ & $\mathrm{OMe}$ & $\mathrm{H}$ & 8.2 & $3 c / 8.2$ & $\mathrm{BCl}_{3} / 0.8$ & $1 \mathrm{~h}$ & $6 \mathbf{a}$ \\
\hline H & $\mathrm{H}$ & $\mathrm{Me}$ & $\mathbf{H}$ & $\mathrm{OMe}$ & $\mathrm{H}$ & 8.4 & $31 / 8.4$ & $\mathrm{BCl}_{3} / 0.8$ & $10 \mathrm{~min}$ & $6 f$ \\
\hline $\mathbf{H}$ & $\mathrm{H}$ & $\mathrm{H}$ & $\mathrm{H}$ & $\mathrm{OMe}$ & $\mathrm{H}$ & 2.0 & $4 c / 2.0$ & $\mathrm{BCl}_{3} / 1.2$ & $1 \mathrm{~h}$ & $6 \mathfrak{a}$ \\
\hline $\mathrm{H}$ & $\mathrm{H}$ & $\mathrm{H}$ & $\mathrm{H}$ & $\mathrm{OMe}$ & $\mathrm{OMe}$ & 0.38 & $4 i / 0.76$ & TMSOTf $/ 0.8$ & $30 \mathrm{~min}$ & $6 e$ \\
\hline $\mathbf{H}$ & $\mathrm{H}$ & $\mathrm{Me}$ & $\mathrm{H}$ & OMe & $\mathrm{H}$ & 3.0 & $41 / 3.0$ & $\mathrm{BCl}_{3} / 1.2$ & $1 \mathrm{~h}$ & $6 f$ \\
\hline $\mathrm{H}$ & $\mathrm{H}$ & $\mathrm{Me}$ & $\mathbf{H}$ & $\mathrm{OMe}$ & $\mathrm{H}$ & 2.6 & $4 t / 2.6$ & $\mathrm{BCl}_{3} / 1.2$ & $1 \mathrm{~h}$ & $6 f$ \\
\hline
\end{tabular}

${ }^{a}$ Key to formula numbers see Scheme III and Table III. ${ }^{b}$ The reactions were carried out at $-78{ }^{\circ} \mathrm{C}$ in $70-100 \mathrm{~mL}$ of $\mathrm{CH}_{2} \mathrm{Cl}_{2}$. ${ }^{c} \mathrm{Not}$ optimized. ${ }^{d}$ Products 6 and/or 7 are formed quantitatively according to the ${ }^{1} \mathrm{H}$ NMR spectra of the crude materials. ${ }^{e} \mathrm{At}^{-30}{ }^{\circ} \mathrm{C}$. ${ }^{f} \mathrm{ZnCl}_{2} \cdot\left(\mathrm{Et}_{2} \mathrm{O}\right)_{1.66}$.

employed for the quantitative determination of the nucleophilicity of allylelement compounds. ${ }^{10}$

\section{Discussion}

Reaction Products. The Lewis acid promoted reactions of diarylmethyl chlorides with allylsilanes 2 , allylgermanes 3 , and allylstannanes 4 usually give rise to the formation of the $S_{E} 2^{\prime}$ products 6 (Table I). Allyltriphenylsilane (2c) gives a mixture of the substitution product 6 and the addition product 7 , while allyldimethyl-tert-butylsilane (2f) and allyltriisopropylsilane (2h) yield the addition products 7 exclusively. In these cases, the bulky substituents shield the silicon atom of the intermediate 5 and direct the anion to the carbenium center, thus giving rise to the formation of 7.

Analogously, those reactions that have been studied kinetically but are not listed in Table I can be expected to give the substitution products 6

Kinetic Experiments. Method and Rate-Determining Step. The method, recently described for the determination of reactivities of carbenium ions toward alkenes, ${ }^{9}$ has also been used for this investigation. As previously reported, various diarylmethyl halides can quantitatively be ionized by Lewis acids such as $\mathrm{BCl}_{3}, \mathrm{SnCl}_{4}$, $\mathrm{TiCl}_{4}, \mathrm{SbCl}_{5}$, or $\mathrm{Me}_{3} \mathrm{SiOTf}$ to give colored solutions with electric conductivity. When compounds 2-4 are added to these solutions, covalent products are formed (Scheme III) and the disappearance of the carbenium ions can be monitored photometrically and conductimetrically. Generally, the rates depend linearly on carbenium ion and on nucleophile concentration; i.e., the reactions follow a second-order rate law. If the formation of the carbenium ion 5 represents the rate-determining step, as indicated in Scheme

(9) (a) Mayr, H.; Schneider, R.; Schade, C.; Bartl, J.; Bederke, R. J. Am. Chem. Soc. 1990, 112, 4446. (b) Schneider, R.; Grabis, U.; Mayr, H. Angew. Chem. 1986, 98, 94; Angew. Chem., Int. Ed. Engl. 1986, 25, 89. (c) Mayr, H.; Schneider, R.; Irrgang, B.; Schade, C. J. Am. Chem. Soc. 1990, 112, 4454.

(10) A preliminary report on the absolute rates of some allylsilanes has been published: Mayr, H.; Hagen, G. J. Chem. Soc., Chem. Commun. 1989,
Table II. Second-Order Rate Constants for the Reaction of AnPhCH${ }^{+}$with Allyltrimethylsilane (2e) in the Presence of Different Counterions $\left(\mathrm{CH}_{2} \mathrm{Cl}_{2},-70^{\circ} \mathrm{C}\right)$

\begin{tabular}{cc}
\hline \multicolumn{1}{c}{ anion } & $\begin{array}{c}k_{2}, \\
\mathrm{~L} \mathrm{~mol}^{-1} \mathrm{~s}^{-1}\end{array}$ \\
\hline $\mathrm{BCl}_{4}^{-}$ & 197 \\
$\mathrm{BCl}_{3}\left(\mathrm{OCH}_{3}\right)^{-a}$ & 194 \\
$\mathrm{SnCl}_{5}^{-}$ & 195 \\
$\mathrm{~F}_{3} \mathrm{CSO}_{3}^{-b}$ & 196 \\
\hline${ }^{a}$ From AnPhCHOCH & $+\mathrm{BCl}_{3}$. ${ }^{b}$ From AnPhCHF + $\mathrm{Me}_{3} \mathrm{SiOTf}$.
\end{tabular}

III, nature and concentration of the counterion $\mathrm{MtX}_{n+1}{ }^{-}$should not affect the overall reaction rate.

Table II shows that the rate of the reaction of $\mathrm{AnPhCH}^{+}$with allyltrimethylsilane (2e) is identical for several counterions, indicating that the slow irreversible attack of the benzhydryl cation at $2 \boldsymbol{e}$ is followed by a fast desilylation of $\mathbf{5}$. Surprisingly, a $10 \%$ reduction of the rate constant has been observed, when the reaction of $\mathrm{AnPhCH} \mathrm{BCl}_{4}^{-}$with $2 \mathrm{e}$ was carried out in presence of $5 \times 10^{-3}$ $\mathrm{M} \mathrm{PhCH}{ }_{2} \mathrm{NEt}_{3}{ }^{+} \mathrm{BCl}_{4}^{-}$. Since nonpaired and paired ions show identical reactivity toward alkenes,, 11 the origin of this salt effect is not clear.

Analogously, the rate of the reaction of $\mathrm{AnPhCH}^{+}$with allyltriphenylgermane (3c) and the rate of the reaction of An(PhOP) $\mathrm{CH}^{+}$with (methylallyl)triphenylgermane (3l) were found to be independent of the nature of the counterion $\left(\mathrm{BCl}_{4}^{-}\right.$or $\mathrm{TfO}^{-}$; Table III). The relatively large difference between the rate constants for the reactions of $\mathrm{AnPhCH}^{+} \mathrm{BCl}_{4}{ }^{-}$and $\mathrm{AnPhCH}+\mathrm{OTf}^{-}$ with 31 is probably due to the high experimental error of these numbers (see individual experiments in the supplementary material).

In contrary, the rate of disappearance of $\mathrm{AnPhCH}^{+}$in the presence of allyltriphenylstannane (4c) was found to be strongly

(11) Mayr, H.; Schneider, R.; Schade, C. Makromol. Chem., Macromol. Symp. 1988, $13 / 14,43$. 
Scheme III

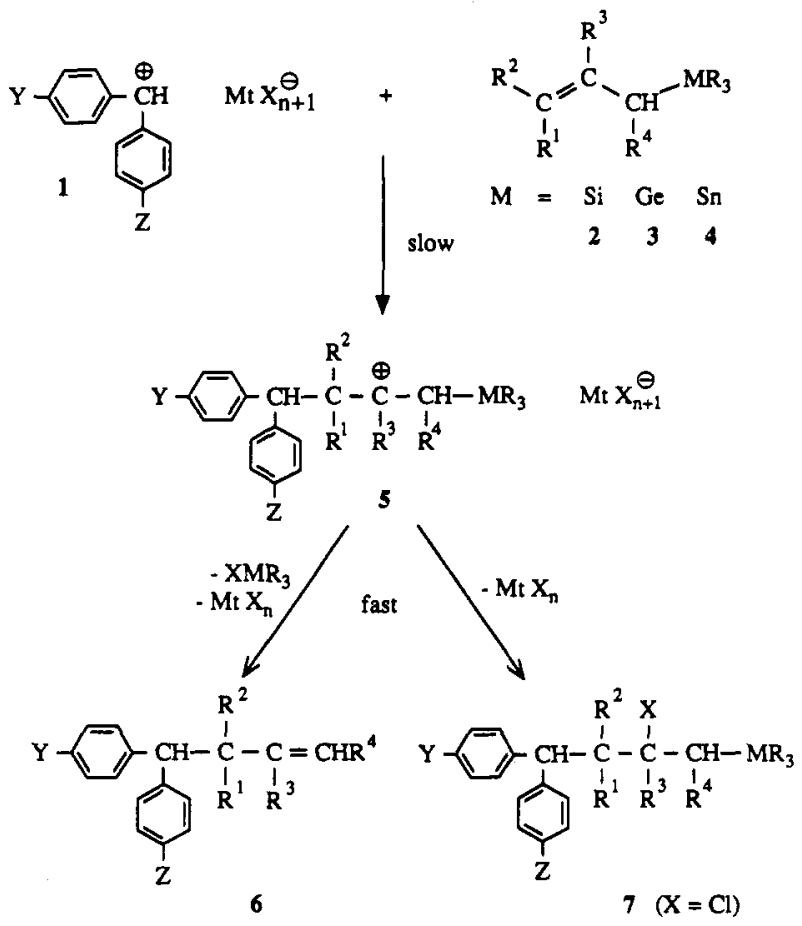

Abbreviations :

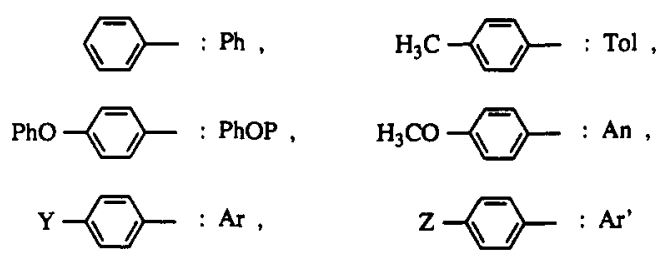

Chart II. Substituent Effect on the Reactivity of Allylsilanes $\mathrm{H}_{2} \mathrm{C}=\mathrm{CHCH}_{2} \mathrm{X}\left(\mathrm{AnPhCH}{ }^{+},-70^{\circ} \mathrm{C}\right)$

$\begin{array}{lllll}\mathrm{X}= & \mathrm{SiMe}_{3} & \mathrm{SiClMe}_{2} & \mathrm{SiPh}_{3} & \mathrm{SiMe}_{2} \mathrm{Ph} \\ & 2 \mathrm{e} & \mathbf{2 b} & 2 \mathrm{c} & \mathbf{2 d} \\ k_{\text {Tel }} & 1.00 & 1 / 678 & 1 / 58 & 1 / 4.8\end{array}$

dependent on the nature of the Lewis acid used for the ionization of $\mathrm{AnPhCHCl}$. This observation is due to the fact that many Lewis acids react rapidly with allylstannanes, even at low temperature. $^{12}$ Analogous to the fast transmetalation reactions between $\mathrm{SnCl}_{4}$ and allylstannanes previously reported, ${ }^{12}$ we observed an instantaneous reaction between $4 \mathrm{c}$ and $\mathrm{BCl}_{3}(<1 \mathrm{~s})$, when these compounds were combined in dichloromethane at -70 ${ }^{\circ} \mathrm{C}$. As allyltributylstannane (4i) was proven not to react with $\mathrm{Me}_{3} \mathrm{SiOTf}$ in $\mathrm{CH}_{2} \mathrm{Cl}_{2}$ at $-70{ }^{\circ} \mathrm{C}$, the metathetic reaction (ArAr'CHHal $+\mathrm{Me}_{3} \mathrm{SiOTf} \rightarrow \mathrm{ArAr}^{\prime} \mathrm{CH}^{+} \mathrm{OTf}^{-}+\mathrm{Me}_{3} \mathrm{SiHal}$ ) was selected to produce solutions of carbenium ions for determining the reactivity of allylstannanes.

In summary, we conclude that the rate constants collected in Table III reflect the rates of attack of the diarylcarbenium ions 1 at the nucleophiles 2-4.

(12) (a) Fishwick, M. F,; Wallbridge, M. G. H. J. Organomet. Chem. 1977, 136, C46. (b) Boaretto, A.; Furlani, D.; Marton, D.; Tagliavini, G. Gambaro, A. J. Organomet. Chem. 1986, 299, 157. (c) Boaretto, A.; Marton, D.: Tagliavini, G.; Ganis, P. J. Organomet. Chem. 1987, 321, 199. (d) Denmark, S. E.; Wilson, T.; Willson, T. M. J. Am. Chem. Soc. 1988, 110 984. (e) Keck, G. E.; Castellino, S.; Andrus, M. B. In Selectivities in Lewis Acid Promoted Reactions; Schinzer, D. Ed.; Kluwer Academic Publishers: Dodrecht, 1989; p 73. (f) Keck, G. E.; Andrus, M. B.; Castellino, S. J. Am Chem. Soc. 1989, 111,8136 . (g) Naruta, Y.; Nishigaichi, Y.; Maruyama, K. Tetrahedron 1989, 45, 1067 and references given therein.

(13) (a) Mayr, H.; Schneider, R.; Grabis U. J. Am. Chem. Soc. 1990, 112, 4460. (b) Schneider, R. Ph.D. Thesis, Universităt Erlangen-Nürnberg, 1987.

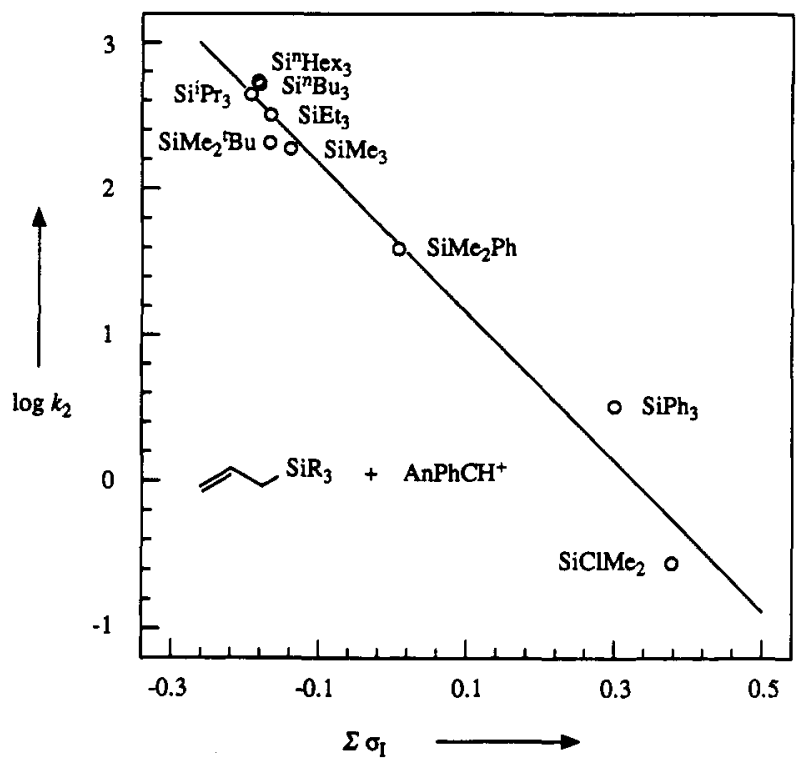

Figure 1. Correlation of the reactivities of the allylsilanes $2 b-j$ toward the p-anisylphenylcarbenium ion $\left(\mathrm{CH}_{2} \mathrm{Cl}_{2},-70^{\circ} \mathrm{C}\right)$ with Taft's inductive substituent constants for the substituents at silicon ( $\log k_{2}=1.664-$ $5.098 \sum \sigma_{1} ; \sigma_{1}=0.47(\mathrm{Cl}), 0.10(\mathrm{Ph}),-0.046(\mathrm{Me}),-0.055(\mathrm{Et}),-0.064$ $\left.(\mathrm{Pr}),-0.060(\mathrm{nBu}),-0.074(\mathrm{tBu}),-0.061(\mathrm{nHex})^{14}\right)$.

Chart III. Relative Reactivities of the Methylallyl Compounds $\mathrm{H}_{2} \mathrm{C}=\mathrm{C}\left(\mathrm{CH}_{3}\right) \mathrm{CH}_{2} \mathrm{X}$ toward $\mathrm{An}_{2} \mathrm{CH}^{+}\left(-70^{\circ} \mathrm{C}\right)$

$\begin{array}{lllll}\mathrm{X}= & \mathrm{SiMe}_{3} & \mathrm{SiPh}_{3} & \mathrm{H}(\text { ref. 13) } & \mathrm{SiCl}_{3}{ }^{a} \\ & 2 \mathrm{~m} & \mathbf{2 l} & \text { isobutene } & 2 \mathrm{k} \\ k_{\text {rel }} & 1.00 & 0.11 & 6.4 \times 10^{-5} & 1.8 \times 10^{-7}\end{array}$

- Estimated from the relative reactivities of $2 \mathbf{k}$ and isobutene toward AnPhCH at $-70^{\circ} \mathrm{C}$.

Chart IV. Relative Reactivities toward $\mathrm{AnPhCH}+\left(\mathrm{CH}_{2} \mathrm{Cl}_{2},-70^{\circ} \mathrm{C}\right)$

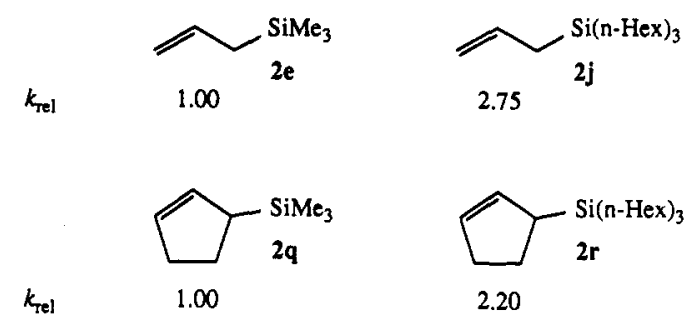

Allylsilanes. Variation of the substituents at silicon changes the reactivity toward $\mathrm{AnPhCH}{ }^{+}$by several orders of magnitude (compounds 2a-j; Table III). Inductively withdrawing substituents reduce the reactivity: According to Chart II, replacement of one methyl group by $\mathrm{Cl}$ retards the electrophilic attack by 3 orders of magnitude $\left(2 \mathrm{e} \rightarrow 2 \mathrm{~b}\right.$ ), while the exchange $\mathrm{CH}_{3} \rightarrow \mathrm{Ph}$ causes a decrease of $k_{2}$ by a factor of $5(2 \mathrm{e} \rightarrow \mathbf{2 d})$. The comparison of compounds $2 e$ and $2 c$ shows that the substituent effects are cumulative.

Figure 1 demonstrates a linear correlation between the reactivities of compounds $\mathbf{2 b}-\mathbf{j}$ and $\sum \sigma_{\mathrm{l}}$, the sum of the inductive substituent constants ${ }^{14}$ for the three ligands at silicon. From the correlation equation given in the caption of Figure 1, one calculates $\log k_{2}\left(\mathrm{AnPhCH}^{+}\right)=-3.03$ for $\sum \sigma_{1}=0.92$. Since this is the rate constant previously determined for the reaction of $\mathrm{AnPhCH} \mathrm{CH}^{+}$with propene, ${ }^{\text {c }}$ one can conclude that replacement of an allylic hydrogen by an alkyldichlorosilyl group $\left(\sum \sigma_{1} \approx 0.89\right)$ should not affect the nucleophilicity of the double bond. For allyltrichlorosilane $(\mathbf{2 a})$, the correlation of Figure 1 predicts a rate

(14) (a) Taft, Jr, R. W. Lewis, I C. J Am. Chem Soc 1958, 80, 2436 (b) Taft, Jr., R. W.; Lewis, I. C. Tetrahedron 1959, 5, 210. (c) Levitt, L. S.; Levitt, B. W. Chem. Ind. (London) 1970,990. (d) Levitt, L. S.; Widing, H. F. Prog. Phys. Org. Chem. 1976, 12, 119. 
Table III. Second-Order Rate Constants for the Reactions of Diarylcarbenium Salts (1, $\left.\mathrm{MtX}_{n+1}{ }^{-}\right)$with the Allylelement Compounds 2-4 in $\mathrm{CH}_{2} \mathrm{Cl}_{2}$

\begin{tabular}{|c|c|c|c|c|c|}
\hline nucleophile & $Y, Z$ of 1 & $\mathrm{MtX}_{n+1}{ }^{-}$ & $\begin{array}{c}k_{2}\left(-70^{\circ} \mathrm{C}\right),{ }^{\circ} \\
\mathrm{L} \mathrm{mol}^{-1} \mathrm{~s}^{-1}\end{array}$ & $\frac{\Delta H^{*}}{\mathrm{~kJ} \mathrm{\textrm {ml } ^ { - 1 }}}$ & $\frac{\Delta S^{*},}{\mathrm{~J} \mathrm{~mol}}$ \\
\hline $\begin{array}{l}\mathrm{H}_{2} \mathrm{C}=\mathrm{CHCH}_{2} \mathrm{SiCl}_{3}(2 \mathrm{a}) \\
\mathrm{H}_{2} \mathrm{C}=\mathrm{CHCH}_{2} \mathrm{SiClMe}_{2}(2 \mathrm{~b}) \\
\mathrm{H}_{2} \mathrm{C}=\mathrm{CHCH}_{2} \mathrm{SiPh}_{3}(2 \mathrm{c}) \\
\mathrm{H}_{2} \mathrm{C}=\mathrm{CHCH}_{2} \mathrm{SiMe}_{2} \mathrm{Ph}(2 \mathrm{~d}) \\
\mathrm{H}_{2} \mathrm{C}=\mathrm{CHCH}_{2} \mathrm{SiMe}_{3}(\mathbf{2 e})^{b}\end{array}$ & $\begin{array}{l}\text { OMe, H } \\
\text { OMe, H } \\
\text { OMe, H } \\
\text { OMe, H } \\
\mathrm{Me}, \mathrm{Me} \\
\mathrm{OPh}, \mathrm{H} \\
\mathrm{OMe}, \mathrm{H} \\
\mathrm{OMe}, \mathrm{Me} \\
\mathrm{OMe}, \mathrm{OMe}\end{array}$ & $\begin{array}{l}\mathrm{BCl}_{4}^{-} \\
\mathrm{BCl}_{4}^{-} \\
\mathrm{BCl}_{4}^{-} \\
\mathrm{BCl}_{4}^{-} \\
\mathrm{BCl}_{4}^{-} \\
\mathrm{BCl}_{4}^{-} \\
\mathrm{BCl}_{4}^{-} \\
\mathrm{BCl}_{4}^{-} \\
\mathrm{BCl}_{4}^{-}\end{array}$ & $\begin{array}{l}\text { no reactn } \\
2.76 \times 10^{-1} \\
3.21 \\
3.87 \times 10^{1} \\
1.77 \times 10^{4} \\
1.89 \times 10^{3} \\
1.87 \times 10^{2} \\
2.63 \times 10^{1} \\
2.81 \times 10^{-1}\end{array}$ & $\begin{array}{l}13.7 \pm 0.1 \\
15.5 \pm 0.4 \\
19.9 \pm 0.2 \\
26.1 \pm 0.1\end{array}$ & $\begin{array}{l}-111 \pm 0.3 \\
-122 \pm 2 \\
-117 \pm 1 \\
-124 \pm 0.4\end{array}$ \\
\hline $\begin{array}{l}\mathrm{H}_{2} \mathrm{C}=\mathrm{CHCH}_{2} \mathrm{SiMe}_{2} \mathrm{tBu}(2 \mathrm{f}) \\
\mathrm{H}_{2} \mathrm{C}=\mathrm{CHCH}_{2} \mathrm{SiEt}(2 \mathrm{~g}) \\
\mathrm{H}_{2} \mathrm{C}=\mathrm{CHCH}_{2} \mathrm{Si}(\mathrm{iPr})_{3}(2 \mathrm{~h}) \\
\mathrm{H}_{2} \mathrm{C}=\mathrm{CHCH}_{2} \mathrm{Si}(\mathrm{nBu})_{3}(2 \mathrm{i}) \\
\mathrm{H}_{2} \mathrm{C}=\mathrm{CHCH}_{2} \mathrm{Si}_{(\mathrm{nHex})_{3}(2 \mathrm{j})} \\
\mathrm{H}_{2} \mathrm{C}=\mathrm{C}\left(\mathrm{CH}_{3}\right) \mathrm{CH}_{2} \mathrm{SiCl}_{3}(2 \mathrm{k}) \\
\mathrm{H}_{2} \mathrm{C}=\mathrm{C}\left(\mathrm{CH}_{3}\right) \mathrm{CH}_{2} \mathrm{SiPh}_{3}(2 \mathrm{l})\end{array}$ & $\begin{array}{l}\text { OMe, H } \\
\text { OMe, H } \\
\text { OMe, H } \\
\text { OMe, H } \\
\text { OMe, H } \\
\text { OMe, H } \\
\text { OMe, H } \\
\text { OMe, OMe } \\
\text { OMe, OMe }\end{array}$ & $\begin{array}{l}\mathrm{BCl}_{4}^{-} \\
\mathrm{BCl}_{4}^{-} \\
\mathrm{BCl}_{4}^{-} \\
\mathrm{BCl}_{4}^{-} \\
\mathrm{BCl}_{4}^{-} \\
\mathrm{BCl}_{4}^{-} \\
\mathrm{BCl}_{4}^{-} \\
\mathrm{BCl}_{4}^{-} \\
\mathrm{OTf}^{-}\end{array}$ & $\begin{array}{l}2.04 \times 10^{2} \\
3.13 \times 10^{2} \\
4.39 \times 10^{2} \\
5.08 \times 10^{2} \\
5.42 \times 10^{2} \\
6.8 \times 10^{-2} \\
1.91 \times 10^{4} \\
5.08 \times 10^{1} \\
5.55 \times 10^{1}\end{array}$ & $200=-8$ & \\
\hline $\mathrm{H}_{2} \mathrm{C}=\mathrm{C}\left(\mathrm{CH}_{3}\right) \mathrm{CH}_{2} \mathrm{SiMe}_{3}(2 \mathrm{~m})$ & $\begin{array}{l}\mathrm{OMe}, \mathrm{H} \\
\mathrm{OMe}, \mathrm{OMe} \\
\mathrm{OMe}, \mathrm{OMe}\end{array}$ & $\begin{array}{l}\mathrm{SnCl}_{5}^{-} \\
\mathrm{BCl}_{4}^{-} \\
\mathrm{OTf}^{-}\end{array}$ & $\begin{array}{l}>10^{5} \\
\text { not reproducible } \\
4.89 \times 10^{2}\end{array}$ & & \\
\hline $\begin{array}{l}(\mathrm{E})-\mathrm{CH}_{3} \mathrm{CH}=\mathrm{CHCH}_{2} \mathrm{SiMe}_{3}(2 \mathrm{n}) \\
(\mathrm{Z})-\mathrm{CH}_{3} \mathrm{CH}=\mathrm{CHCH}_{2} \mathrm{SiMe}_{3}(2 \mathrm{o}) \\
\left(\mathrm{CH}_{3}\right)_{2} \mathrm{C}=\mathrm{CHCH} \mathrm{SiMe}_{3}(2 \mathrm{p})\end{array}$ & $\begin{array}{l}\text { OMe, H } \\
\text { OMe, H } \\
\text { OPh, H } \\
\text { OMe, H } \\
\text { OMe, Me } \\
\text { OPh, OMe }\end{array}$ & $\begin{array}{l}\mathrm{BCl}_{4}^{-} \\
\mathrm{BCl}_{4}^{-} \\
\mathrm{BCl}_{4}^{-} \\
\mathrm{BCl}_{4}^{-c} \\
\mathrm{BCl}_{4}^{-c} \\
\mathrm{BCl}_{4}^{-c}\end{array}$ & $\begin{array}{l}4.19 \times 10^{3} \\
1.66 \times 10^{3} \\
2.00 \times 10^{4} \\
1.52 \times 10^{3} \\
9.02 \times 10^{1} \\
2.62\end{array}$ & $\begin{array}{r}8.6 \pm 0.1 \\
\\
3.1 \pm 0.2 \\
8.9 \pm 0.2 \\
13.8 \pm 0.4\end{array}$ & $\begin{array}{l}-130 \pm 0.5 \\
-166 \pm 1 \\
-160 \pm 1 \\
-166 \pm 2\end{array}$ \\
\hline$\Longrightarrow-\operatorname{sine}_{3}(2 q)$ & $\mathrm{OMe}, \mathrm{H}$ & $\mathrm{BCl}_{4}^{-}$ & $1.30 \times 10^{3}$ & & \\
\hline$-\mathrm{Si}(\mathrm{nHex})_{3}(2 \mathrm{r})$ & $\mathrm{OMe}, \mathrm{H}$ & $\mathrm{BCl}_{4}^{-}$ & $2.81 \times 10^{3}$ & & \\
\hline $\begin{array}{l}\left(\mathrm{CH}_{3}\right)_{2} \mathrm{C}=\mathrm{C}\left(\mathrm{CH}_{3}\right) \mathrm{CH}_{2} \mathrm{SiEt}_{3}(2 \mathrm{~s}) \\
\mathrm{H}_{2} \mathrm{C}=\mathrm{CHCH} \mathrm{CHePh}_{3}(3 \mathrm{c})\end{array}$ & $\begin{array}{l}\text { OMe, OMe } \\
\text { OMe, H }\end{array}$ & $\begin{array}{l}\mathrm{BCl}_{4}^{-c} \\
\mathrm{BCl}_{4}^{-} \\
\mathrm{OTf}^{-}\end{array}$ & $\begin{array}{l}1.3 \times 10^{3} \\
1.56 \times 10^{1} \\
1.79 \times 10^{1}\end{array}$ & & \\
\hline $\mathrm{H}_{2} \mathrm{C}=\mathrm{C}\left(\mathrm{CH}_{3}\right) \mathrm{CH}_{2} \mathrm{GePh}_{3}(3 \mathrm{l})$ & $\begin{array}{l}\text { OMe, H } \\
\text { OMe, Me } \\
\text { OMe, OPh }\end{array}$ & $\begin{array}{l}\mathrm{BCl}_{4}^{-} \\
\mathrm{OTf}^{-} \\
\mathrm{BCl}_{4}^{-} \\
\mathrm{BCl}_{4}^{-} \\
\mathrm{OTf}^{-}\end{array}$ & $\begin{array}{l}\sim 1.8 \times 10^{4 d} \\
\sim 2.5 \times 10^{4 d} \\
7.31 \times 10^{3} \\
6.00 \times 10^{2} \\
6.17 \times 10^{2}\end{array}$ & & \\
\hline $\mathrm{H}_{2} \mathrm{C}=\mathrm{CHCH}_{2} \mathrm{SnPh}_{3}(4 \mathrm{c})$ & $\begin{array}{l}\text { OMe, OMe } \\
\text { OMe, H }\end{array}$ & $\begin{array}{l}\mathrm{OTf}^{-} \\
\mathrm{TiCl}_{5}^{-} \\
\mathrm{OTf}^{-}\end{array}$ & $\begin{array}{l}1.38 \times 10^{2} \\
2.46 \times 10^{3} \\
5.18 \times 10^{3 e}\end{array}$ & & \\
\hline $\begin{array}{l}\mathrm{H}_{2} \mathrm{C}=\mathrm{CHCH}_{2} \mathrm{Sn}(\mathrm{nBu})_{3}(4 \mathrm{i}) \\
\mathrm{H}_{2} \mathrm{C}=\mathrm{C}\left(\mathrm{CH}_{3}\right) \mathrm{CH}_{2} \mathrm{SnPh}_{3}(41) \\
\mathrm{H}_{2} \mathrm{C}=\mathrm{C}\left(\mathrm{CH}_{3}\right) \mathrm{CH}_{2} \mathrm{Sn}(\mathrm{nBu})_{3}(4 \mathrm{t})\end{array}$ & $\begin{array}{l}\text { OMe, Me } \\
\text { OMe, OPh } \\
\text { OMe, OMe } \\
\text { OMe, OMe } \\
\text { OMe, OMe } \\
\text { OMe, OMe }\end{array}$ & $\begin{array}{l}\text { OTf } \\
\text { OTf } \\
\text { OTf } \\
\text { OTf } \\
\text { OTf } \\
\text { OTf }\end{array}$ & $\begin{array}{l}6.95 \times 10^{2} \\
5.0 \times 10^{1} \\
1.01 \times 10^{1} \\
5.07 \times 10^{3} \\
2.40 \times 10^{3} \\
>5 \times 10^{4}\end{array}$ & & \\
\hline
\end{tabular}

${ }^{a}$ If $k_{2}$ has been measured at variable temperature, the entry in this column refers to the value derived from the Eyring equation; therefore, slight deviations of these data from those directly measured at $-70^{\circ} \mathrm{C}$ (Table II and ref 10 ) are possible. ${ }^{b}$ From ref 13 . ' ${ }^{c}$ Experiments carried out in presence of $\mathrm{PhCH}_{2} \mathrm{NEt}_{3}{ }^{+} \mathrm{BCl}_{4}^{-}$. ${ }^{d}$ These numbers should be considered to be lower limits of $k_{2}$ and are not used for the correlations of Table V1. 'Selected value, see text.

constant of $3 \times 10^{-6} \mathrm{~L} \mathrm{~mol}^{-1} \mathrm{~s}^{-1}$, in agreement with the observation that this compound does not react noticeably with $\mathrm{AnPhCH}^{+}$, even at $-30^{\circ} \mathrm{C}$.

An analogous reactivity sequence $\left(\mathrm{SiMe}_{3}>\mathrm{SiPh}_{3} \gg \mathrm{H}>\right.$ $\mathrm{SiCl}_{3}$ ) is also found in the methylallyl series (Chart III). ${ }^{15}$

Compounds $2 f$ and $2 \mathrm{~h}$ match the relationship depicted in Figure 1 though they are giving addition (7) and not substitution products (6). This finding corroborates our conclusion that the formation of the intermediate $\mathbf{S}$ is rate-determining and that product control takes place after the rate-determining step. The small but steady increase of reactivity, which accompanies the increase of the alkyl groups at silicon $(\mathbf{2 e} \rightarrow \mathbf{2} \mathbf{j})$, is correlated with the inductive substituent constants (Figure 1). The contribution of conformational effects cannot a priori be excluded, however, since the magnitude of the hyperconjugative effect strongly depends on the dihedral angle between the allylic $\mathrm{C}-\mathrm{Si}$ bond and the $\pi_{\mathrm{CC}}$-orbitals.

(15) The ligands on silicon also affect the stereoselectivities of electrophilic attack at vinylsilanes: Brook, M. A.; Neuy, A. J. Org. Chem. 1990, 55, 3609.
Table IV. Effect of Methyl Groups in the 2-Position of Allylsilanes $\left(\mathrm{CH}_{2} \mathrm{Cl}_{2},-70^{\circ} \mathrm{C}\right)$

\begin{tabular}{|c|c|c|}
\hline electrophile & $\mathrm{X}$ & $k\left(\sim \gamma^{x}\right)$ \\
\hline $\begin{array}{l}\mathrm{AnPhCH} \mathrm{PH}^{+} \\
\mathrm{AnPhCH} \mathrm{PhC}^{+} \\
\mathrm{An}_{2} \mathrm{CH}^{+}\end{array}$ & $\begin{array}{l}\mathrm{H} \\
\mathrm{SiPh}_{3} \\
\mathrm{SiMe}_{3}\end{array}$ & $\begin{array}{l}2.5 \times 10^{4 a} \\
6.0 \times 10^{3} \\
1.7 \times 10^{3}\end{array}$ \\
\hline
\end{tabular}

'Reference $9 \mathrm{c}$.

In order to differentiate these effects, we have compared the relative reactivities of the conformationally flexible allyl compounds $2 e$ and $\mathbf{j}$ with those of the analogously substituted cyclopentenyl compounds $\mathbf{2 q}$ and $\mathbf{r}$. According to Chart IV, replacement of methyl by $n$-hexyl causes a similar rate increase in the cyclic as in the acyclic compounds, thus ruling out the operation of conformational effects and leaving the previously quoted inductive effects. 
Table V. Effect of Methyl Groups at the Electrophilically Attacked Vinylic Position (AnPhCH ${ }^{+},-70^{\circ} \mathrm{C}$ )

\begin{tabular}{|c|c|c|c|}
\hline $\mathrm{R}=\mathrm{CH}_{3}$ or $\mathrm{H}$ & $k_{\mathrm{CH}_{3}} / k_{\mathrm{H}}$ & $\Delta H_{\mathrm{CH}_{3}}{ }^{*}-\Delta H_{\mathrm{H}}{ }^{*}$ & $\Delta S_{\mathrm{CH}_{3}}{ }^{*}-\Delta S_{\mathrm{H}}{ }^{*}$ \\
\hline $\mathrm{SiM}_{\theta_{3}}$ & 22 & -6.9 & -8 \\
\hline $\mathrm{iMe}_{3}$ & 8.9 & & \\
\hline $\mathrm{SiMe}_{3}$ & 8.1 & -12.4 & -44 \\
\hline
\end{tabular}

Substituent Variation at the CC Double Bond. As previously reported for alkenes, ${ }^{9 c}$ the introduction of a methyl group at the developing carbenium center causes an increase of reactivity by more than 3 orders of magnitude. While a methyl group in the 2-position of propene ( $\rightarrow$ isobutene) accelerates by 25000 (Table IV), the effect decreases to become 6000 for allyltriphenyisilane $(2 \mathrm{c} \rightarrow 2 \mathrm{l})$ and 1700 for allyltrimethylsilane $(2 \mathrm{e} \rightarrow 2 \mathrm{~m})$, thus revealing a saturation effect. The change of the reference electrophile in the last entry of Table IV does not affect the discussion, since the relative reactivities of terminal vinyl derivatives are independent of the reactivity of the electrophile (see below and ref 13 ).

In complete analogy to the effects previously reported for alkenes (Table II of ref 9c), methyl groups at the initially attacked vinyl positions favor the approach of electrophiles enthalpically but disfavor it entropically (Table V). At $-70^{\circ} \mathrm{C}$, the enthalpic effect is dominating, and the crotyl silanes $2 n$ and $o$ as well as the dimethyl-substituted compound $2 p$ are by 1 order of magnitude more reactive toward $\mathrm{AnPhCH}{ }^{+}$than the parent compound $2 \mathrm{e}$. As a consequence of the different slopes of the LFERs discussed below, the activation by methyl groups at the initially attacked vinyl position will grow with increasing reactivity of the carbenium ions. On the other hand, one can extrapolate that carbenium ions of low electrophilicity will react faster with allyltrimethylsilane (2e) than with the methyl-substituted counterparts $2 \mathbf{n}-\mathbf{p}$.

While cyclopentene reacts 7 times faster with $\mathrm{AnPhCH} \mathrm{CH}^{+}$than $(Z)$-butene, ${ }^{9 c}$ the cyclopentenylsilane $2 q$ is even slightly less reactive than the crotylsilane 20 (Table III). Obviously, the trimethylsilyl group activates the conformationally flexible acyclic alkene to a higher degree than the cyclopentene, probably because angle strain has to be built up when the trimethylsilyl group is going to adopt an orientation optimal for the hyperconjugative stabilization of the cyclopentyl cation. ${ }^{16}$

Comparison of Allylsilanes, -germanes, and -stannanes. The reactivity of these compounds covers a wide range, and a single reference electrophile is not sufficient for a kinetic comparison. We have, therefore, selected the carbenium ions $\mathrm{AnPhCH}^{+}$and $\mathrm{An}_{2} \mathrm{CH}^{+}$to quantify the nucleophilicity of these compounds. The left column of Chart $\mathrm{V}$ lists the relative reactivities of allylsilanes, -germanes, and -stannanes toward $\mathrm{AnPhCH}^{+}$in comparison to propene. Since the rate of the reaction of allyltributylstannane (4i) with $\mathrm{AnPhCH}{ }^{+}$cannot be measured directly, we derived this value from the relative reactivities of $4 \mathrm{i}$ and $4 \mathrm{c}$ toward $\mathrm{An}_{2} \mathrm{CH}^{+}$ (Table III) assuming identical selectivities of these two carbenium ions (see below). Analogously, the $k_{\text {rel }}$ value of the trichlorosilyl compound $2 \mathbf{k}$ in Chart $\mathbf{V}$ has been estimated from the relative reactivity of isobutene and $2 \mathrm{k}$ toward $\mathrm{AnPhCH}$. In order to allow a direct graphic comparison of the nucleophiles in the two columns of Chart $\mathrm{V}$, the two sets of data have been arranged in such a way that the positions of isobutene and propene, the two reference compounds, reflect their relative reactivities toward $\mathrm{AnPhCH}{ }^{+}$ $\left(k_{\mathrm{rel}}=2.48 \times 10^{4}\right) .9 \mathrm{c}$ Comparison of compounds $2 \mathrm{c}, 3 \mathrm{c}$, and $4 \mathrm{c}$ (left column of Chart V) shows that the reactivity increases by 1 order of magnitude from $\mathrm{Si}$ to $\mathrm{Ge}$ and by 2 orders of magnitude from $\mathrm{Ge}$ to $\mathrm{Sn}$, reflecting the relative magnitudes of the ionization potentials of $\mathrm{H}_{2} \mathrm{C}=\mathrm{CHCH}_{2} \mathrm{MMe}_{3}$ determined by photoelectron spectroscopy $(\mathrm{M}=\mathrm{Si}, 9.0 \mathrm{eV} ; \mathrm{Ge}, 8.85 \mathrm{eV} ; \mathrm{Sn}, 8.50 \mathrm{eV}) .{ }^{17} \mathrm{An}$

(16) Wang, G.; Li, D.; Chelius, E. C.; Lambert, J. B. J. Chem. Soc., Perkin Trans. 21990,331 .
Chart V. Relative Nucleophilicities of Allylsilanes, -germanes, and -stannanes with Respect to Propene (Left) and Isobutene (Right) ${ }^{b}$

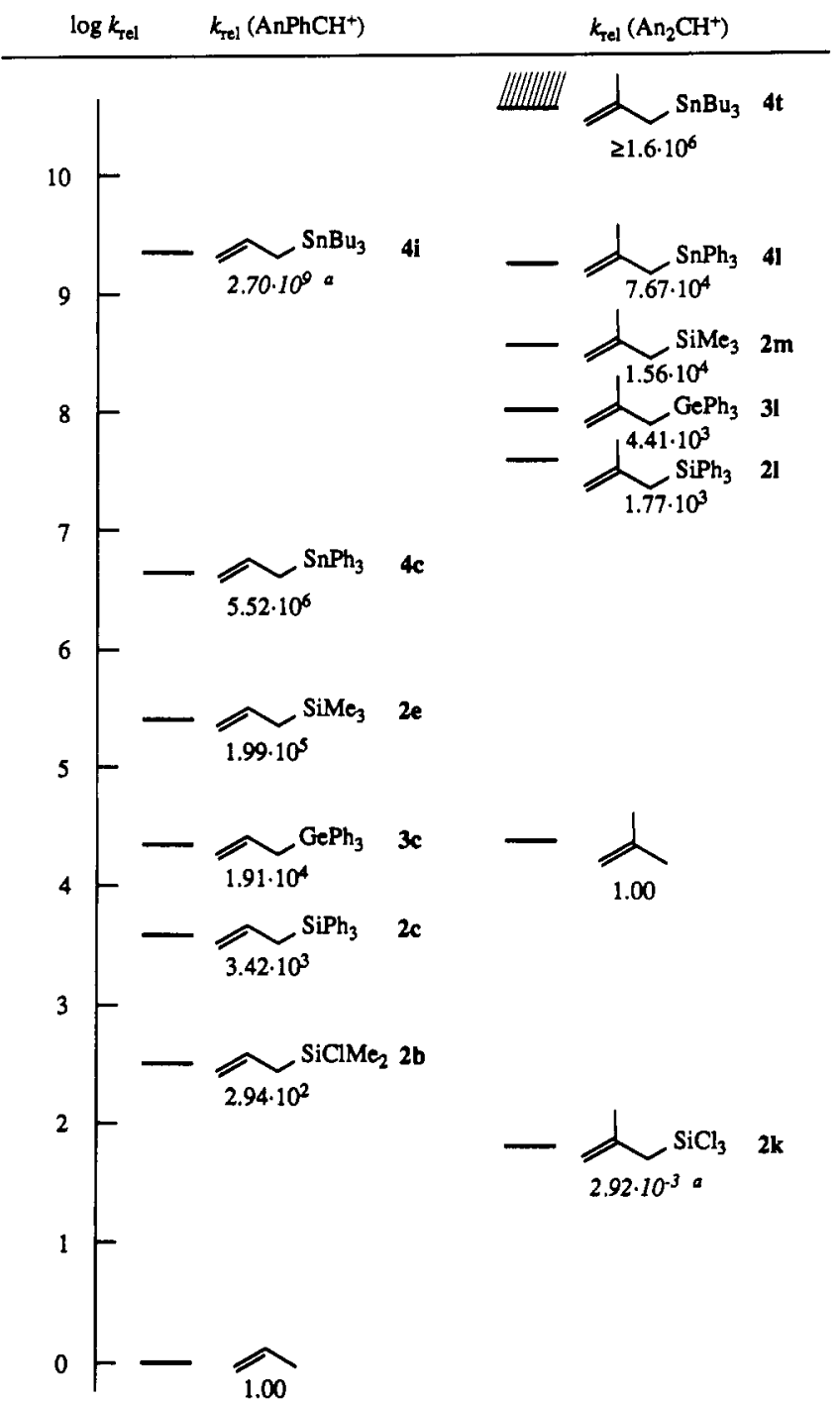

a Extrapolated values; see text. ${ }^{b}$ The graphic representation allows a direct comparison of all compounds; i.e., the nucleophilicities of $3 c$ and isobutene are almost identical.

analogous reactivity pattern is found in the methylallyl series in the right column of Chart V, but compounds 21,31 , and 41 differ less in reactivity than their lower homologues $(2 c-4 c)$ due to the saturation effect. In analogy to the reactivity ratio $2 \mathrm{e} / 2 \mathrm{c}$ that has been explained by the different inductive effects of alkyl and phenyl groups (see above), the $\mathrm{SnBu}_{3}$ group is found to be a considerably stronger electron donor than the $\mathrm{SnPh}_{3}$ group (Chart $\mathrm{V}, \mathbf{4 i} / \mathbf{4 c}$ and $\mathbf{4 t} / \mathbf{4 l}$ ). Since allylgermanes are only slightly more reactive than analogously substituted allylsilanes, the allyltriphenylgermanes 3c (Chart V, left) and 31 (Chart V, right) are located in between the $\mathrm{Ph}_{3} \mathrm{Si}$ - and $\mathrm{Me}_{3} \mathrm{Si}$-substituted derivatives, respectively.

A comparison of the reactivities of the allylelement compounds 2-4 with the corresponding hydrocarbons propene and isobutene yields the magnitude of the $\beta$-element effect. From the reactivity ratio $2 \mathrm{e} /$ propene, one derives a $\beta-\mathrm{SiMe}_{3}$ effect of 5 orders of magnitude (slightly greater than that obtained from competition experiments with respect to $\left.\mathrm{Ph}_{2} \mathrm{CH}^{+}\right),{ }^{4}$ and the $\beta-\mathrm{SnBu}_{3}$ effect amounts to 9 orders of magnitude ( $4 \mathrm{i} /$ propene). Again, the $\beta$-element effect is somewhat smaller in the right column of Chart $V$ because of the saturation effect.

(17) Schweig, A.; Weidner, U.; Manuel, G. J. Organomet. Chem. 1973, 54,$145 ; 1974,67, \mathrm{C} 4$. 


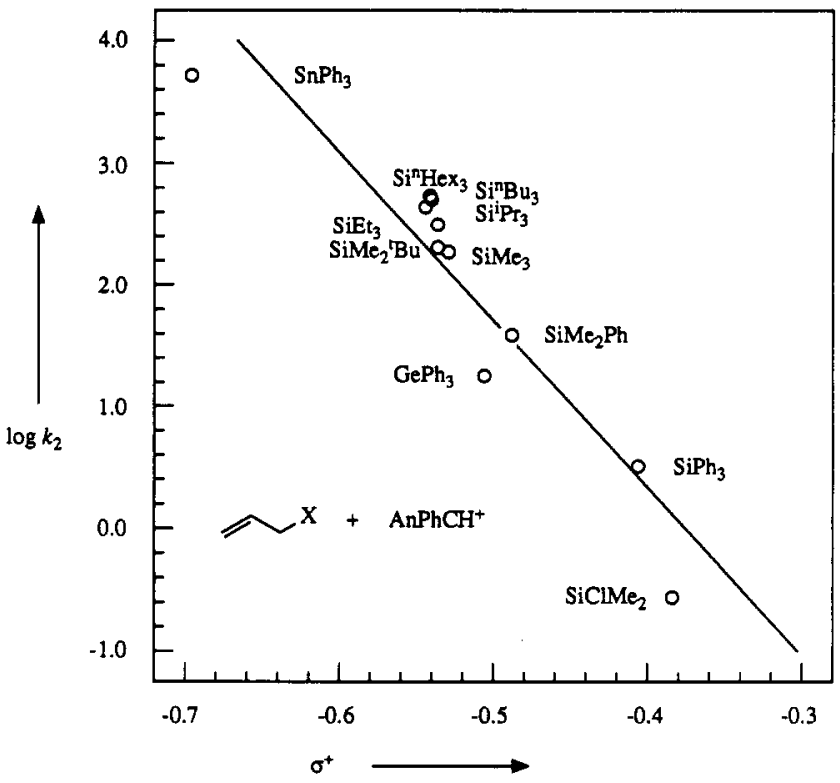

Figure 2. Correlation of the reactivities of the allyl compounds $\mathrm{H}_{2} \mathrm{C}=$ $\mathrm{CHCH}_{2} \mathrm{X}$ toward AnPhCH${ }^{+}\left(-70^{\circ} \mathrm{C}\right)$ with Davis' $\sigma^{+}$substituent constants $\left(\log k_{2}=-4.974-13.56 \sigma^{+}\right)$; for the definition of $\sigma^{+}$see eq 1 .

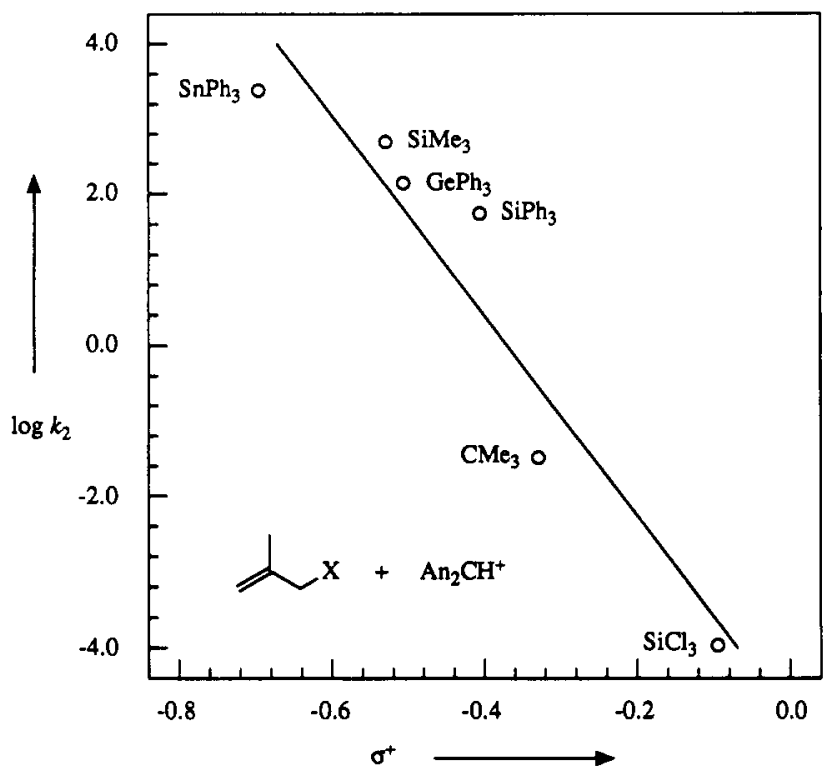

Figure 3. Correlation of the reactivities of the methylallyl compounds $\mathrm{H}_{2} \mathrm{C}=\mathrm{C}\left(\mathrm{CH}_{3}\right) \mathrm{CH}_{2} \mathrm{X}$ toward $\mathrm{An}_{2} \mathrm{CH}^{+}\left(-70^{\circ} \mathrm{C}\right)$ with Davis' $\sigma^{+}$substituent constants $\left(\log k_{2}=-4.924-13.29 \sigma^{+}\right.$; the points for $\mathrm{X}=\mathrm{CMe}_{3}$ and $\mathrm{SiCl}_{3}$ are extrapolated from experiments with $\mathrm{AnPhCH}^{+}$); for the definition of $\sigma^{+}$see eq 1 .

Benzylsilanes, -germanes, and -stannanes give CT complexes with tetracyanoethylene and maleic anhydride, ${ }^{18}$ and Davis has used the absorption frequences of these complexes to derive $\sigma^{+}$ values for $-\mathrm{CH}_{2} \mathrm{MR}_{3}$ substituents. ${ }^{19}$ The substituent constants thus derived have been expressed by eq 1 , where $\sum \sigma_{1}$ is the sum

$$
\sigma^{+}={ }^{*} \sigma_{\mathrm{R}}{ }^{+n}+0.28 \sum \sigma_{\mathrm{l}}
$$

of the inductive substituent constants for the three substituents on the metal ( $\sigma_{I}$ values; ${ }^{14}$ see caption of Figure 1 ) and ${ }^{~} \sigma_{R}{ }^{+*}$ is a measure of the resonance or hyperconjugative interaction of the $-\mathrm{CH}_{2} \mathrm{MR}_{3}$ group ( ${ }^{\circ} \sigma_{\mathrm{R}}{ }^{+n}=-0.29(\mathrm{C}),-0.49(\mathrm{Si}),-0.59(\mathrm{Ge})$, $-0.78(\mathrm{Sn}))$. Though only moderate correlations between the nucleophilicities of the compounds $2-4$ and the substituent con-

(18) (a) Hanstein, W.; Berwin, H. J.; Traylor, T. G. J. Am. Chem. Soc. 1970, 92, 829. (b) Traylor, T. G.; Berwin, H. J.; Jerkunica, J.; Hall, M. L. Pure Appl. Chem. 1972, 30, 599 .

(19) Davis, D. D. J. Organomet. Chem. 1981, 206, 21.

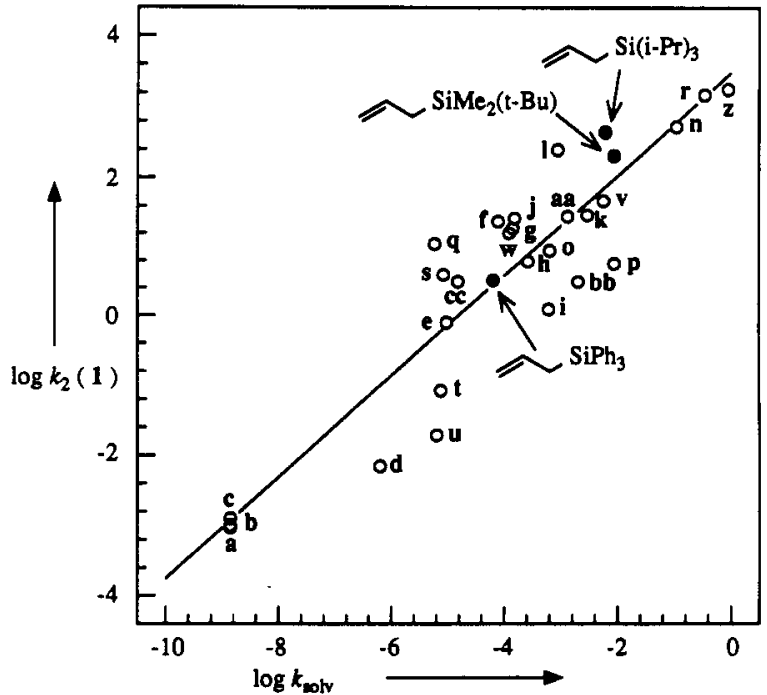

Figure 4. Correlation of the reactivities of alkenes, dienes (letters refer to ref $9 \mathrm{c})$, and allylsilanes toward $\mathrm{AnPhCH}^{+}\left(-70^{\circ} \mathrm{C}\right)$ with the solvolysis rates of the diarylmethyl chloride adducts $\left(80 \%\right.$ ethanol, $\left.50^{\circ} \mathrm{C}\right)$.

Scheme IV<smiles>[R]C([R])(Cl)C([R])([R])[13CH][13CH3]</smiles><smiles>[R]C([R])=C([R])[R]</smiles>

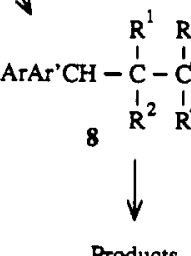

stants $\sigma^{+}$are found (Figures 2 and 3 ), the correlation equations given in the captions of these figures provide a rough estimate for the nucleophilicity of allylelement compounds with widely varying substituents.

The rate constants for the reactions of $\mathrm{AnPhCH}^{+}$with alkenes were reported to be correlated with the solvolysis rates of the addition products, ${ }^{9 c}$ in accord with the assumption that the transition states of both reactions resemble the carbenium ion 8 (Scheme IV).

We have now analogously studied the solvolysis rates of the addition products $7 \mathrm{a}\left(k_{\text {solv }}=6.34 \times 10^{-5} \mathrm{~s}^{-1}\right), 7 \mathrm{~b}\left(k_{\text {solv }}=8.53 \times\right.$ $\left.10^{-3} \mathrm{~s}^{-1}\right)$, and $7 \mathrm{c}\left(k_{\text {solv }}=5.98 \times 10^{-3} \mathrm{~s}^{-1}\right)$ in $80 \%$ aqueous ethanol $(\mathrm{v} / \mathrm{v})$ at $50^{\circ} \mathrm{C},{ }^{20}$ and Figure 4 shows that the entries for the allylsilanes perfectly match this correlation, again stressing the analogy between electrophilic additions to alkenes and to allylsilanes. The correlation of Figure 4, furthermore, shows that solvolysis rates of $\beta$-element-substituted substrates may be used for estimating nucleophilicities of allylelement compounds.

Variation of the Carbenium Ions. Linear Free Energy Relationships. The close analogy between the reactivities of carbenium ions toward alkenes and allylelement compounds, repeatedly mentioned above, suggests a comparison of the kinetic data in more detail. For this purpose, the reactivities of those allylelement compounds, which have been combined with several benzhydryl cations, are plotted versus the corresponding rate constants of 2-methyl-1-pentene, ${ }^{9}$ in analogy to our previous treatment of alkene reactivities. ${ }^{13}$ Figure 5 shows a linear correlation between the reactivities of the different reaction series, which is mathematically expressed by eq 2 .

$$
\log k_{2}=s \log k_{0}+c
$$

(20) Schade, C. Ph.D. Thesis, Medizinische Universität Lübeck, 1988. 
Table VI. Correlations between the Reactivities of Diarylcarbenium Ions (ArAr' $\left.\mathrm{CH}^{+}\right)$toward $\pi-\mathrm{Nucleophiles}\left(-70^{\circ} \mathrm{C}, \mathrm{CH}_{2} \mathrm{Cl}_{2}\right)^{a}$

\begin{tabular}{llrl}
\hline \multicolumn{1}{c}{ nucleophile } & \multicolumn{1}{c}{$c$} & $r$ (no. of points) \\
\hline $\mathrm{H}_{2} \mathrm{C}=\mathrm{C}\left(\mathrm{CH}_{3}\right) \mathrm{C}_{3} \mathrm{H}_{7}$ & 1.00 & 0.00 & ref reactn \\
styrene $^{13}$ & $0.978 \pm 0.017$ & $-0.418 \pm 0.033$ & $0.9992(7)$ \\
$\mathrm{H}_{2} \mathrm{C}=\mathrm{CHCH}_{2} \mathrm{SiMe}_{3}(2 e)^{13}$ & $0.950 \pm 0.006$ & $0.918 \pm 0.012$ & $0.99995(5)$ \\
$\left(\mathrm{CH}_{3}\right)_{2} \mathrm{C}=\mathrm{CHCH}_{2} \mathrm{SiMe}_{3}(2 \mathrm{p})$ & $1.217 \pm 0.037$ & $1.361 \pm 0.055$ & $0.9991(4)$ \\
$\mathrm{H}_{2} \mathrm{C}=\mathrm{C}\left(\mathrm{CH}_{3}\right) \mathrm{CH}_{2} \mathrm{GePh}_{3}(3 \mathrm{l})$ & $0.835 \pm 0.004$ & $3.424 \pm 0.004$ & $0.99999(3)$ \\
$\mathrm{H}_{2} \mathrm{C}=\mathrm{CHCH}_{2} \mathrm{SnPh}_{3}(4 \mathrm{c})$ & $0.912 \pm 0.014$ & $2.397 \pm 0.016$ & $0.9998(4)$ \\
\hline
\end{tabular}

${ }^{\circ}$ Correlations according to eq 2: $\log k_{0}=3.531\left(\mathrm{Tol}_{2} \mathrm{CH}^{+}\right), 2.456\left(\left(\mathrm{PhOP}_{\mathrm{PhCH}}{ }^{+}\right), 1.412\left(\mathrm{AnPhCH}^{+}\right), 0.529(\mathrm{AnTolCH}),-0.772(\mathrm{An}-\right.$ $\left.(\mathrm{PhOP}) \mathrm{CH}^{+}\right),-1.535\left(\mathrm{An}_{2} \mathrm{CH}^{+}\right)$from ref $9 \mathrm{a}$.

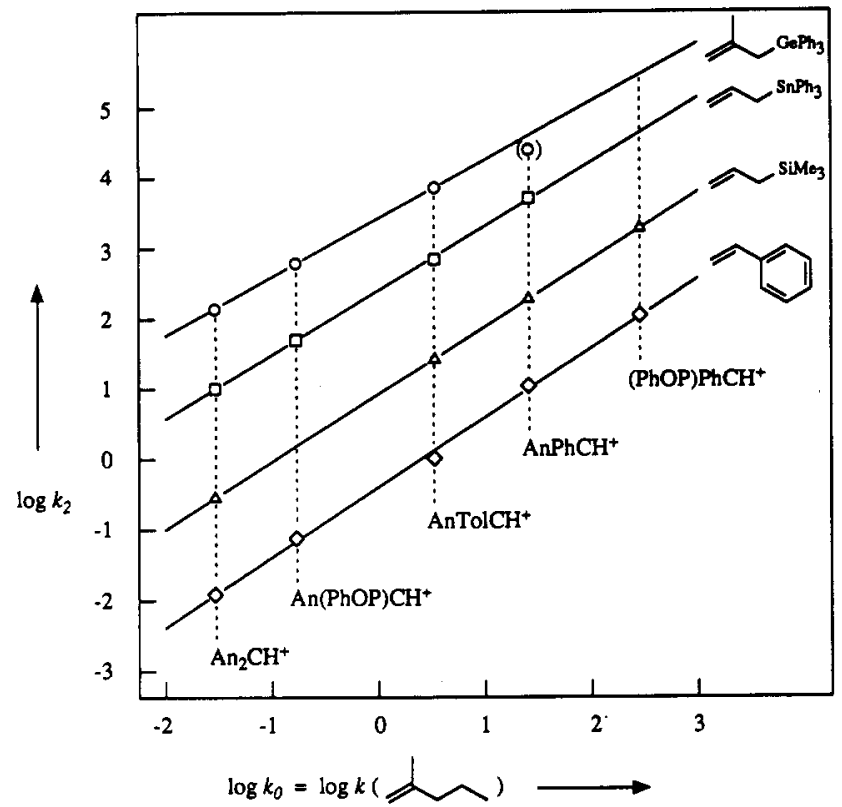

Figure 5. Correlation of the reactivities of various allylelement compounds and styrene toward diarylcarbenium ions $\left(\mathrm{ArAr}^{\prime} \mathrm{CH}^{+}\right)$with the corresponding reactivities of 2-methyl-1-pentene $\left(\mathrm{CH}_{2} \mathrm{Cl}_{2},-70^{\circ} \mathrm{C}\right)$.

Since the same reference reaction $\left(k_{0}\right.$ for $\mathrm{ArAr}^{\prime} \mathrm{CH}^{+}+2-$ methyl-1-pentene, $\mathrm{CH}_{2} \mathrm{Cl}_{2},-70^{\circ} \mathrm{C}$ ) is used as in ref 13 , the $s$ and $c$ values given in Table VI are directly comparable to the corresponding $s$ and $c$ values for alkenes listed in Table II of ref 13.

Table VI shows that the $s$ values (slopes in Figure 5) for the terminal vinyl compounds $2 \mathbf{2 e}, \mathbf{3 1}, \mathbf{4 c}$, and styrene are closely similar and slightly smaller than 1 , while compound $2 p$ with two methyl groups at the electrophilically attacked vinylic position (not shown in Figure 5) is characterized by a considerably greater value of s. This behavior is perfectly analogous to that observed for alkenes, where $s$ ranges from 0.948 to 1.00 for terminal alkenes and adopts a value of $s=1.39$ for tetramethylethylene. ${ }^{13}$

What is the physical meaning of the parameter $s$ ? In previous work, we have shown that the reactivities of the carbenium ions 1 toward alkenes $\left(\Delta G^{*}\right)$ are linearly correlated with the ground-state energies of these carbenium ions, expressed by the equilibrium constants of the ionization reaction (eq 3). ${ }^{9 a, 13}$ For terminal alkenes, $\alpha$ values (eq 4) between 0.63 and 0.67 have been

$$
\begin{gathered}
\operatorname{ArAr} r^{\prime} \mathrm{CHCl}+\mathrm{BCl}_{3} \frac{\Delta G_{1}^{\circ}}{\mathrm{CH}_{2} \mathrm{Cl}_{2},-70^{\circ} \mathrm{C}} \mathrm{ArAr}^{\prime} \mathrm{CH}^{+} \mathrm{BCl}_{4}^{-} \\
\Delta G^{*}=-\alpha \Delta G_{1}^{\circ}+\text { constant }
\end{gathered}
$$

found, and since a productlike transition state should be characterized by $\alpha \approx 1$, we concluded that, in the transition states, approximately two-thirds of the positive charge has been transferred from the diarylmethyl fragment to the nucleophile. ${ }^{13}$ With $\alpha=0.67$ for the reference reaction $\left(\mathrm{ArAr}^{\prime} \mathrm{CH}^{+}+2\right.$-methyl-1pentene; $s=1),{ }^{13}$ the relationship $\alpha=0.67 s$ results, so $s=1 / 0.67$ $=1.5$ should indicate a productlike transition state, while $s$ values close to 0 are expected for reactantlike transition states. ${ }^{21}$

(21) For detailed discussions of the significance of $\alpha$ for locating transition states, see: (a) Thea, S.; Williams, A. Chem. Soc. Rev. 1986, 15, 125. (b) Pross, A. Adv. Phys. Org. Chem. 1985, 21, 99.
The $s$ values in Table VI, therefore, show that the reactions of allylelement compounds with terminal vinyl groups proceed through earlier transition states than the corresponding reactions of the allylsilane $2 p$. This conclusion is in accord with the relative magnitudes of the activation entropies (Table III).

The almost parallel lines in Figure 5 illustrate that variation of the para substituents in the carbenium ions 1 has a similar effect on the reactivity of terminal alkenes, allylsilanes, allylgermanes, and allylstannanes; i.e., the relative reactivities of these nucleophiles $(\sim \Delta c)$ are almost independent of the reactivity of the electrophile, and the nucleophilicity parameter $c$ (eq 2 and Table VI) corresponds to $N_{0}$ in Ritchie's constant selectivity relationship. ${ }^{22}$

As $k_{0}$ (reactivity of $\mathrm{ArAr}^{\prime} \mathrm{CH}^{+}$toward 2-methyl-1-pentene) has also been determined for carbenium ions not included in this investigation, ${ }^{9}$ rate constants for the reactions of these carbenium ions with allylelement compounds can also be calculated from eq 2. It has, furthermore, been reported ${ }^{13}$ that the correlations (eqs 5 and 6 ), which are of lower quality than eq 2 , allow the prediction of rate constants for the reactions of alkenes with diarylcarbenium ions on the basis of the $s$ and $c$ parameters for alkenes and the $\mathrm{p} K_{\mathrm{R}}+$ values $^{23}$ or the ethanolysis rate constants $\left(k_{\text {solv }} ; 25^{\circ} \mathrm{C}\right)$ for the corresponding benzhydryl chlorides. ${ }^{24}$ These equations can

$\log k_{2}\left(\mathrm{CH}_{2} \mathrm{Cl}_{2},-70^{\circ} \mathrm{C}\right)=-7.42 s-1.07 s\left(\mathrm{p} K_{\mathrm{R}^{+}}\right)+c(5)$

$\log k_{2}\left(\mathrm{CH}_{2} \mathrm{Cl}_{2},-70^{\circ} \mathrm{C}\right)=0.90 s-1.26 s \log k_{\text {solv }}+c$

analogously be used for estimating rate constants of the allylelement compounds listed in Table VI, and since the magnitude of $s$ is similar for compounds with identical substitution at the electrophilically attacked vinylic position, one can also obtain rough estimates for rate constants of $\pi$-nucleophiles, for which only the reactivity toward one benzhydryl cation is known. ${ }^{25}$ Recent studies suggest that the validity of eq 6 may not be restricted to diarylmethyl electrophiles, for which it has been derived. ${ }^{26}$

Conclusion. The attack of carbenium ions at allylsilanes, allylgermanes, and allylstannanes occurs in exactly the same way as the corresponding attack at ordinary alkenes; i.e., these allylelement compounds can be regarded as donor-substituted ethylenes. The perfectly linear and almost parallel reactivity correlations (Figure 5) corroborate our previous conclusion that the transition-state structure is hardly affected, when the changes of reactivity are caused by structural variations distant from the reaction centers. ${ }^{13,26}$ Structural variations at the reaction center (comparison $2 p / 2 e$ ), on the other hand, affect the transition-state structure $\left(\Delta S^{*}\right.$, slope of the LFER), even if the structural variations have only a slight impact on the reaction rates.

Since the relative reactivities of terminal alkenes and allylelement compounds 2-4 with terminal groups are almost independent of the electrophilicity of the carbenium ions, Chart V can be considered to be a general nucleophilicity scale that experiences only minor changes when the carbon electrophile is altered.

\section{Experimental Section}

The kinetic method has been described. ${ }^{\text {gn }}$ Diarylmethyl chlorides have been synthesized according to ref 27 .

(22) (a) Ritchie, C. D. Acc. Chem. Res. 1972, 5, 348. (b) Ritchie, C. D. Can. J. Chem. 1986, 64, 2239.

(23) (a) Deno, N. C.; Jaruzelski, J.; Schriesheim, A. J. Am. Chem. Soc. 1955, 77, 3044. (b) Deno, N. C.: Schriesheim, A. Ibid. 1955, 77, 3051.

(24) Schade, C.; Mayr, H. Tetrahedron 1988, 44, 5761.

(25) Details of this procedure are given in ref 13 .

(26) Review: Mayr, H. Angew. Chem. 1990, 102, 1415; Angew. Chem. Int. Ed. Engl. 1990, 29, 1371. 
Allylsilanes. The reaction of allylmagnesium chloride with the corresponding chlorosilanes in diethyl ether ${ }^{28}$ was used for preparation of $2 \mathrm{c}\left(62 \%, \mathrm{mp} 89.5-90.5^{\circ} \mathrm{C}\right.$ from ether (lit. $\left.\left.{ }^{29} \mathrm{mp} 84-86^{\circ} \mathrm{C}\right)\right), 2 \mathrm{~g}(83 \%$, bp $25-30^{\circ} \mathrm{C}$ (bath) (1-2 mbar) (lit. ${ }^{30}$ bp $\left.37^{\circ} \mathrm{C}(3 \mathrm{mmHg})\right)$ ), and $2 \mathrm{i}$ (93\%, bp $55-65{ }^{\circ} \mathrm{C}$ (bath) $(0.1 \mathrm{mbar})$ (lit. ${ }^{31}$ bp $145-146{ }^{\circ} \mathrm{C}(12$ mmHg))). Compounds $2 f\left(65 \%\right.$, bp $70-75^{\circ} \mathrm{C}$ (bath) $\left(55\right.$ mbar) (lit. ${ }^{32}$ bp $\left.65-66^{\circ} \mathrm{C}(47 \mathrm{mmHg})\right)$ ), $2 \mathrm{~h}\left(81 \%\right.$, bp $45-55^{\circ} \mathrm{C}$ (bath) (0.2 mbar) (lit. ${ }^{33}$ bp $\left.\left.130^{\circ} \mathrm{C}(16 \mathrm{mmHg})\right)\right), 2 \mathrm{j}\left(90 \%\right.$, bp $115-125^{\circ} \mathrm{C}$ (bath) $(0.2$ mbar)), 21 ( $72 \%, \mathrm{mp} 90-91^{\circ} \mathrm{C}$ from ether/hexane), $2 \mathrm{~m}(60 \%$, bp $64-68$ ${ }^{\circ} \mathrm{C}$ (260 mbar) (lit. 34 bp $\left.109^{\circ} \mathrm{C}\right)$ ), $24\left(74 \%\right.$, bp $97-99^{\circ} \mathrm{C}$ (290 mbar) (lit. ${ }^{33}$ bp $\left.140-146^{\circ} \mathrm{C}\right)$, and $2 \mathrm{r}\left(62 \%\right.$, bp $109-119^{\circ} \mathrm{C}$ (bath) $\left(4 \times 10^{-5}\right.$ mbar)) have been synthesized by adding allyl chlorides to mixtures of $\mathrm{Mg}$ and chlorosilanes with ultrasound irradiation in spite of the fact that this method, which has been developed for the synthesis of allylstannanes, ${ }^{36}$ has been stated not to be applicable to the synthesis of allylsilanes: A solution of an allyl chloride $(110 \mathrm{mmol})$ in THF $(120 \mathrm{~mL})$ was added dropwise $(\sim 0.5 \mathrm{~h})$ to a mixture of $\mathrm{Mg}$ turnings $(165 \mathrm{mmol})$, a piece of iodine, trialkylchlorosilane $(60 \mathrm{mmol})$, and THF $(55 \mathrm{~mL})$ at $0{ }^{\circ} \mathrm{C}$ with irradiation of ultrasound. The mixture was kept another 30 min at $0^{\circ} \mathrm{C}$ (ultrasound) and was then heated at $40-50^{\circ} \mathrm{C}$ for $4 \mathrm{~h}$. After hydrolysis with aqueous $\mathrm{NH}_{4} \mathrm{Cl} / \mathrm{NH}_{3}$ solution and separation of the layers, the aqueous layer was extracted with diethyl ether and the combined organic layers were dried over $\mathrm{MgSO}_{4}$ and distilled to give the allylsilanes listed above.

Compound $2 \mathrm{~d}$ (bp 50-60 ${ }^{\circ} \mathrm{C}$ (bath) (2-3 mbar) (lit. ${ }^{37}$ bp $96-97{ }^{\circ} \mathrm{C}$ $(14 \mathrm{mmHg}))$ ) was obtained via reaction of allyl chloride with dimethylphenylsilyl lithium in THF $^{38}$ in $71 \%$ yield. The combination of trichlorosilane with allyl chloride or methylallyl chloride in the presence of $\mathrm{CuCl}$ and triethylamine gave compounds $2 \mathrm{a}\left(73 \%\right.$, bp $117^{\circ} \mathrm{C}(1$ bar) $\left.{ }^{39}\right)$ and (2-methylallyl)trichlorosilane (2k) $\left(78 \%\right.$, bp $139^{\circ} \mathrm{C}(1$ bar $\left.)^{39}\right)$, respectively. The analogous reaction with crotyl chloride gave a $9 / 1$ mixture of $(E)$ - and $(Z)$-crotyltrichlorosilane $\left(79 \%\right.$, bp $143^{\circ} \mathrm{C}(1$

(27) Schneider, R.; Mayr, H.; Plesch, P. H. Ber. Bunsen-Ges. Phys. Chem. $1987,91,1369$.

(28) Organikum, 15th ed,; Autorenkollektiv, VEB Deutscher Verlag der Wissenschaften: Berlin, 1976; $\mathrm{p} 623$.

(29) Henry, M. C.; Noltes, J. G. J. Am. Chem. Soc. 1960, 82, 555.

(30) Coulson, D. R. J. Org. Chem. 1973, 38, 1483.

(31) Topchiev, A. V.; Nametkin, N. S.; Durgar'yan, S. G.; Irsled. v Obl. Kremniiorgan. Soedin., Sintez i Fiz-Khim. Svoistva, Akad. Nauk SSSR, Inst. Neftekhim Sinteza, Sb. Statei 1962, 28; Chem. Abstr. 59, 1670g. 835 .

(32) Morita, T.; Okamoto, Y.; Sakurai, H. Tetrahedron Lett. 1980, 21,

(33) Muchowski, J. M.; Naef, R.; Maddox, M. L. Tetrahedron Lett. 1985, 26, 5375 .

(34) Petrov, A. D.; Nikishin, G. I.; Smetankina, N. P. Zh. Obshch. Khim. 1958, 28, 2085; Chem. Abstr. 53, 3038g.

(35) Reuter, J. M.; Sinha, A.; Salomon, R. G. J. Org. Chem. 1978, 43, 2438.

(36) Naruta, Y.; Nishigaichi, Y.; Maruyama, K. Chem. Lett. 1986, 1857. (37) (a) Wilt, J. W.; Chwang, W. K.; Dockus, C. F.; Tomiuk, N. M. J. Am. Chem. Soc. 1978, 100, 5534. (b) Soderquist, J. A.; Hassner, A. J. Org. Chem. 1983, 48, 1801.

(38) Ager, D. J.; Fleming, I.; Patel, S. K. J. Chem. Soc., Perkin Trans. l 1981, 2520

(39) Furuya, N.; Sukawa, T. J. Organomet. Chem. 1975, 96, C1: bar $\left.)^{39}\right)$, which was treated with methylmagnesium iodide to give $62 \%$ of a mixture $\left(2 \mathrm{n} / 20=9 / 1\right.$; bp $60-70^{\circ} \mathrm{C}$ (bath) (108 mbar) (lit. ${ }^{40} \mathrm{bp}$ $110-118^{\circ} \mathrm{C}$ )), from which $2 \mathrm{n}$ was isolated by preparative gas chromatography. The pure $Z$-isomer 20 (bp $80^{\circ} \mathrm{C}$ (bath) $(270 \mathrm{mbar})$ ) was synthesized in $53 \%$ yield by irradiation $(360 \mathrm{~nm}$ ) of a mixture of 1,3butadiene and trimethylsilane in the presence of catalytic amounts of $\mathrm{Cr}(\mathrm{CO})_{6}{ }^{41}$ The analogous photochemical hydrosilation of 2,3-dimethyl-1,3-butadiene gave $2 \mathrm{~s}$ (bp $58-60^{\circ} \mathrm{C}$ (bath) ( 2 mbar) (lit. ${ }^{42}$ bp $\left.55^{\circ} \mathrm{C}(0.3 \mathrm{~mm} \mathrm{Hg})\right)$ ) in $71 \%$ yield.

Allylgermanes. Treatment of bromotriphenylgermane (preparation by bromination of tetraphenylgermane ${ }^{43}$ ) with $\mathbf{M g}$ and allyl chloride or methylallyl chloride in an ultrasound bath, as described above for the allylsilanes, gave the allylgermanes $3 \mathrm{c}\left(\mathrm{mp} 88-89^{\circ} \mathrm{C}\right.$ (lit. ${ }^{44} \mathrm{mp} 90-91.5$ $\left.{ }^{\circ} \mathrm{C}\right)$ ) and $31\left(\mathrm{mp} 87-88.5^{\circ} \mathrm{C}\right)$, respectively.

Allylstannanes. Naruta's procedure, ${ }^{36}$ i.e., dropwise addition of allyl chlorides to mixtures of chlorostannanes and $\mathbf{M g}$ in THF with ultrasound irradiation, afforded the compounds $4 \mathrm{c}\left(78 \%, \mathrm{mp} 73-74^{\circ} \mathrm{C}\right.$ from ether (lit. $\left.{ }^{45,46} \mathrm{mp} 72.5-74^{\circ} \mathrm{C}(4 \mathrm{mmHg})\right)$ ), $41\left(77 \%, \mathrm{mp} 72-73^{\circ} \mathrm{C}\right.$ from pentane/ether $\left.{ }^{45}\right)$, and $4 \mathrm{t}\left(83 \%\right.$, bp $95-100^{\circ} \mathrm{C}$ (bath) (0.4 mbar) (lit. ${ }^{47}$ bp $\left.\left.121-122^{\circ} \mathrm{C}(4 \mathrm{mmHg})\right)\right)$.

Products from the Reaction of 1 with 2-4. A Lewis acid is added to the solution of $\mathrm{ArAr}^{\prime} \mathrm{CHCl}$ in $\mathrm{CH}_{2} \mathrm{Cl}_{2}$ at $-78{ }^{\circ} \mathrm{C}$, which causes the solution to adopt a yellow or red color. The nucleophiles are added, and after fading of the colors the solutions are washed with aqueous ammonia and dried over $\mathrm{CaCl}_{2}$ and the solvents are evaporated to yield compounds 6 and/or 7. Details of the reactions are given in Table I, and the characterization of the products can be found in the supplementary material.

Acknowledgment. We thank Gaby Horter and Claudia Rieper for experimental assistance, Reinhard Schneider for carrying out the experiments with $2 p$, and Christian Schade for performing the solvolytic investigations of compounds 7 . Financial support by the Deutsche Forschungsgemeinschaft and the Fonds der Chemischen Industrie is gratefully acknowledged.

Supplementary Material Available: ${ }^{1} \mathrm{H}$ NMR and (partially) ${ }^{13} \mathrm{C}$ NMR data for compounds $2-4$ and $6-7$ and tables with rate constants of the individual kinetic runs (19 pages). Ordering information is given on any current masthead page.

(40) (a) Sakurai, H.; Kudo, Y.; Miyoshi, H. Bull. Chem. Soc. Jpn. 1976, 49, 1433. (b) Alberts, V.; Cuthbertson, M. J.; Hawker, D. W.; Wells, P. R. Org. Magn. Reson. 1984, 22, 556.

(41) Wrighton, M. S.; Schroeder, M. A. J. Am. Chem. Soc. 1974, 96 , 6235 .

(42) Hill, J. E.; Nile, T. A. J. Organomet. Chem. 1977, 137, 293.

(43) Băhr, G.; Kalinowski, H.-O. Organo-Germanium- und -Zinn-Verbindungen. Houben-Weyl, Methoden der Organischen Chemie, 4th ed.; Georg Thieme Verlag: Stuttgart, 1987; Vol. XIII/6, pp 23, 69.

(44) Gilman, H.; Gerow, C. W. J. Am. Chem. Soc. 1957, 79, 342.

(45) Seyferth, D.; Weiner, M. A. J. Org. Chem. 1961, 26, 4797.

(46) Abel, E. W.; Rowley, R. J. J. Organomet. Chem. 1975, 84, 199

(47) (a) Naruta, Y. J. Am. Chem. Soc. 1980, 102, 3774. (b) Keck, G. E.;

Enholm, E. J.; Yates, J. B.: Wiley, M. R. Tetrahedron 1985, $41,4079$.

(48) Harris, R. K.; Sebald, A. Magn. Reson. Chem. 1987, 25, 1058. 